\title{
Hybrid Materials Based on Carbon Nanotubes and Polyaromatic Molecules: Methods of Functionalization and Sensor Properties
}

\author{
Tamara V. Basova ${ }^{a}$ and Maxim S. Polyakov ${ }^{b}$ \\ ${ }^{a}$ Nikolaev Institute of Inorganic Chemistry SB RAS, 630090 Novosibirsk, Russia \\ ${ }^{\mathrm{b}}$ Saint Petersburg State University of Architecture and Civil Engineering, 190005 Saint Petersburg, Russia \\ ${ }^{\circledR}$ E-mail: basova@niic.nsc.ru
}

\begin{abstract}
One of the most relevant ways to improve selectivity of sensors based on carbon nanotubes (CNT) is to create hybrid materials with polyaromatic molecules. The interest in hybrid materials is related to the synergistic effect that occurs when the properties of carbon nanomaterials (their one-dimensional electronic structure, high conductivity, large surface area) and properties of polyaromatic molecules (high sensitivity to analytes of different nature, reversibility of the sensor response) are combined. The creation of new porous three-dimensional carbon structures, in which polyaromatic molecules are linkers, is also of interest for creating functional carbon materials of a new generation. This review analyzes the current state of research in the field of hybrid materials based on carbon nanotubes and various polyaromatic molecules (derivatives of phthalocyanine, porphyrin, pyrene, coumarin, BODIPY, etc.) related to the problems of improving the sensitivity and selectivity of chemiresistive and electrochemical sensors. The first part of the review presents an analysis of works that describe various methods of functionalization of carbon nanotubes with aromatic molecules, and examines their influence on the composition and structure of the resulting materials, as well as approaches to creating hybrid $3 D$ structures based on CNTs. The second part of the review is devoted to the functional properties of hybrid materials with the main focus on the analysis of their sensor properties. Examples of the most successful application of hybrid materials as active layers of chemiresistive sensors for determining various gases in the environment are given. When considering the literature data, the main attention is paid to the analysis of the influence of methods of CNT functionalization with polyaromatic molecules on sensor properties. The third part of the review is devoted to the use of hybrid materials for the modification of electrodes of electrochemical sensors for the determination of various molecules in aqueous solutions and biological media.
\end{abstract}

Keywords: Hybrid materials, carbon nanotubes, metal phthalocyanines, polyaromatic molecules, chemiresistive sensors, electrochemical sensors.

\section{Гибридные материалы на основе углеродных нанотрубок и полиароматических молекул: методы функционализации и сенсорные свойства}

\section{Т. В. Басова, ${ }^{\mathrm{a} @}$ М. С. Поляков ${ }^{\mathrm{b}}$}

\footnotetext{
аФедеральное государственное бюджетное учреждение науки Институт неорганической химии им. А.В. Николаева Сибирского отделения Российской академии наук, 630090 Новосибирск, Россия

${ }^{b}$ Федеральное государственное бюджетное образовательное учреждение выстего образования «Санкт-

Петербургский государственный архитектурно-строительный университет», 190005 Санкт-Петербург, Россия

${ }^{\circledR}$ E-mail: basova@niic.nsc.ru
}

Одним из актуальных путей улучшения селективности сенсоров на основе углеродных нанотрубок (УНТ)
является создание гибридных материалов с полиароматическими молекулами. Интерес к гибриднылм мате-
риалам связан с синергетическим эффектом, возникающзим при комбинации свойств углеродных материалов 
(их псевдоодномерная электронная структура, высокая проводимость, большая площадь поверхности) и свойств полиароматических молекул (высокая чувствительность к определяемым веществам различной природы, обратимость сенсорного отклика). Создание новых пористых трёхмерных углеродных структур, в которых полиароматические молекулы являются линкерами, также представляет интерес для создания функииональных углеродных материалов нового поколения. В настоящем обзоре проанализировано современное состояние исследований в области получения гибридных материалов на основе углеродных нанотрубок и различных полиароматических молекул (производных фталоцианина, порфирина, пирена, кумарина, BODIPY и др.), связанных с проблемами улучшения чувствительности и селективности адсорбиионно-резистивньх и электрохимических сенсоров. В первой части обзора представлен анализ работ, в которых описываются различные методы функиионализации углеродных нанотрубок ароматическими молекулами и изучается их влияние на состав и структуру получаемых материалов, а также рассмотрены подходы к созданию гибридных $3 D$ структур на основе УНТ. Вторая часть обзора посвящена функциональным свойствам гибридных материалов, при этом основное внимание уделяется анализу их сенсорных свойств. Приведены примеры наиболее успешного применения гибридных материалов в качестве активных слоев адсорбиионно-резистивных сенсоров для определения различных газов в окружаюшей среде. При рассмотрении литературных данных уделяется внимание анализу влияния методов функичионализации углеродных нанотрубок полиароматическими молекулами на сенсорные свойства. Третья часть обзора посвящена использованию гибридных материалов для модифицирования электродов электрохимических сенсоров для определения различных молекул в водных растворах и биологических жидкостях.

Ключевые слова: Гибридные материалы, углеродные нанотрубки, фталоцианинаты металлов, полиароматические молекулы, адсорбционно-резистивные сенсоры, электрохимические сенсоры.

\section{Introduction}

Hybrid materials play an important role in the development of nanotechnology due to the synergetic combination of properties of two or more components to create new types of functional materials with distinctive electrical, optical or mechanical properties. ${ }^{[1]}$ When considering a large family of nanocarbon materials, carbon nanotubes (CNT) are among the most attractive for the preparation of active layers of gas sensors due to their high conductivity, large surface area and adsorption capacity. ${ }^{[2]}$

Conductivity of semiconductor carbon nanotubes can change when different molecules adsorb on their surface. Strong electron acceptors (e.g. $\mathrm{NO}_{2}$ ) significantly increase the conductivity of CNTs by increasing the charge carriers, namely holes. On the other hand, reducing gases that are electron donors lead to a decrease of their conductivity due to recombination of electrons and holes. Currently, the sensor characteristics of CNTs towards various gases (e.g. $\mathrm{NH}_{3}$, $\mathrm{NO}_{2}, \mathrm{CH}_{4}, \mathrm{SO}_{2}, \mathrm{H}_{2} \mathrm{~S}$ ) and organic solvent vapours (e.g. ethanol, acetone and chloroform) have been studied. ${ }^{[3-5]}$ Another practical aspect of CNTs and their hybrid materials is their use for the modification of electrodes of electrochemical sensors. ${ }^{[6]}$ The successful use of carbon nanotubes as sensitive layers has a number of limitations, including their low selectivity to analytes, long response and regeneration times, and low reproducibility. The latter may be because of the difficulty of reproducible deposition of homogeneous films due to the tendency of CNTs to uncontrollable aggregation in suspensions and, as a result, formation of bundles. One of the ways to overcome these limitations is to modify or functionalize carbon nanotubes using various functional groups, polymer or aromatic molecules. The interest in hybrid materials is due to the synergistic effect arising from the combination of properties of carbon nanomaterials (their one-dimensional electronic structure, high conductivity, large surface area) and the properties of polyaromatic molecules (e.g. high sensitivity to analytes, reversibility of the sensor response). In addition, preparation of hybrid materials allows reducing uncontrolled aggregation of carbon nanotubes and obtaining fine dispersions in organic solvents for the deposition of uniform thin layer suitable for the study of their optical and electrical properties.

In recent years, several reviews summarizing data on hybrid materials on the basis of nanocarbon with organic derivatives have been published. ${ }^{[7,8]}$ Most of them were devoted to the synthetic aspects of the functionalization of carbon nanomaterials, such as fullerenes, graphene, single-wall (SWCNT) and multi-wall (MWCNT) carbon nanotubes, with various molecules including polymers, phthalocyanines (MPc), and some others. The application of certain types of carbon-based hybrids for chemical sensing has also been mentioned in several works, ${ }^{\left[{ }^{[]}\right.}$but they have not been generalized in a single review. For example, Lewandowski et al ${ }^{[8]}$ described the detection mechanisms of sensors on the basis of CNTs and their hybrids with porphyrins towards different gases $\left(\mathrm{NH}_{3}, \mathrm{NO}_{2}, \mathrm{CO}_{2}\right.$, etc. $)$ and volatile organic compounds (VOC), while Zhou et $a l .{ }^{[9]}$ summarized the data on application of noncovalently functionalized carbon nanotubes for the modification of electrodes of biosensors.

This review analyzes the state of research over the last ten years in the field of hybrid materials based on carbon nanotubes and various polyaromatic molecules (derivatives of phthalocyanine, porphyrin, pyrene, coumarin, BODIPY, etc.) related to the problems of improving the sensitivity and selectivity of chemiresistive and electrochemical sensors. 


\section{Methods of Functionalization of Carbon Nanotubes by Polyaromatic Molecules}

\section{Noncovalent Functionalization}

Noncovalent functionalization is one of the approaches for regulating the interfacial properties of nanotubes. It is based on supramolecular interaction using various adsorption forces, such as hydrogen and Van der Waals bonds, electrostatic forces, and $\pi$-stacking interaction. This approach does not require chemically aggressive media or harsh physical influences and is easier to implement than the covalent functionalization method. In addition, noncovalent functionalization does not lead to a violation of the electronic structure of initial carbon nanomaterials. ${ }^{[10,11]}$ The main disadvantage of noncovalent attachment is that the forces between the wrapping molecule and the nanotube may be weak, and the functionalization degree may be lower than in the case of covalent functionalization. ${ }^{[12]}$

$\pi-\pi$-Interactions play the most important role in noncovalent functionalization of CNTs with aromatic molecules. Woods et al.$^{[13]}$ studied the adsorption of benzene derivatives on SWCNT using density functional theory and found that the adsorption was mainly achieved by the interaction of p-orbitals of the benzene ring and those of the CNT. For this reason, organic molecules with extended aromatic system, e.g. pyrene, ${ }^{[14-17]}$ porphyrin ${ }^{[18-23]}$ and phthalocyanine ${ }^{[24-29]}$ derivatives, are widely used for the modification of carbon nanomaterials due to their ability to form specific and $\pi$ - $\pi$-stacking contacts between aromatic molecules and the graphite surface of CNT. Noncovalent functionalization of carbon nanotubes leads also to an increase of CNT solubility ${ }^{[30]}$ and improvement of photoinduced electron transfer properties, ${ }^{[15,24,31]}$ sensing properties, ${ }^{[17,32-35]}$ mechanical and thermal properties, ${ }^{[16,36-39]}$ and catalytic effect. ${ }^{[40,41]}$
Several techniques of noncovalent functionalization of carbon nanotubes are known. If aromatic compounds are soluble in water or organic solvents their hybrid materials are prepared by mixing their solutions with CNT dispersions in various solvents with or without ultrasonic treatment. Then the excess of adsorbed molecules is removed by washing in appropriate solvents. ${ }^{[42]}$ If polyaromatic molecules (e.g. unsubstituted metal phthalocyanines) have low solubility their hybrid materials are prepared by noncovalent functionalization of carbon nanotubes via mixing suspensions of carbon nanotubes and MPcs in dimethylformamide (DMF) or acetonitrile under ultrasonic treatment. ${ }^{[43]}$ Another approach relies on in situ synthesis of phthalocyanine in the presence of carbon nanotubes. ${ }^{[44-48]}$ Basiuk et al. ${ }^{[49]}$ suggested a simple, efficient and environmentally friendly method of deposition of unsubstituted MPcs with $\mathrm{M}=\mathrm{Co}$, $\mathrm{Ni}, \mathrm{Cu}$ and $\mathrm{Zn}$ onto CNT sidewalls, in which the functionalization was performed by heating SWCNT-MPc mixtures in a quartz reactor under moderate vacuum $\left(10^{-2}\right.$ Torr) at $400-500{ }^{\circ} \mathrm{C}$. MPc was sublimed, part of it was adsorbed on the nanotube sidewalls, and the excess was condensed in the cooler part of reactor right above the edge of tube furnace. The MPc weight content in the prepared hybrids was determined by termogravimetric analysis (TGA) to be 30,17 and $35 \%$ for $\mathrm{NiPc}, \mathrm{CuPc}$ and $\mathrm{ZnPc}$, respectively.

The examples of application of the above mentioned techniques for the preparation of active layers of chemiresistive and electrochemical sensors will be described in the corresponding sections below.

\section{Covalent Functionalization}

The main strategy of covalent functionalization has been described in a number of reviews ${ }^{[50-53]}$ and book chapters. ${ }^{[54-57]}$ CNTs tend to aggregate into bundles, which makes it difficult to disperse them in solvents. Thus,

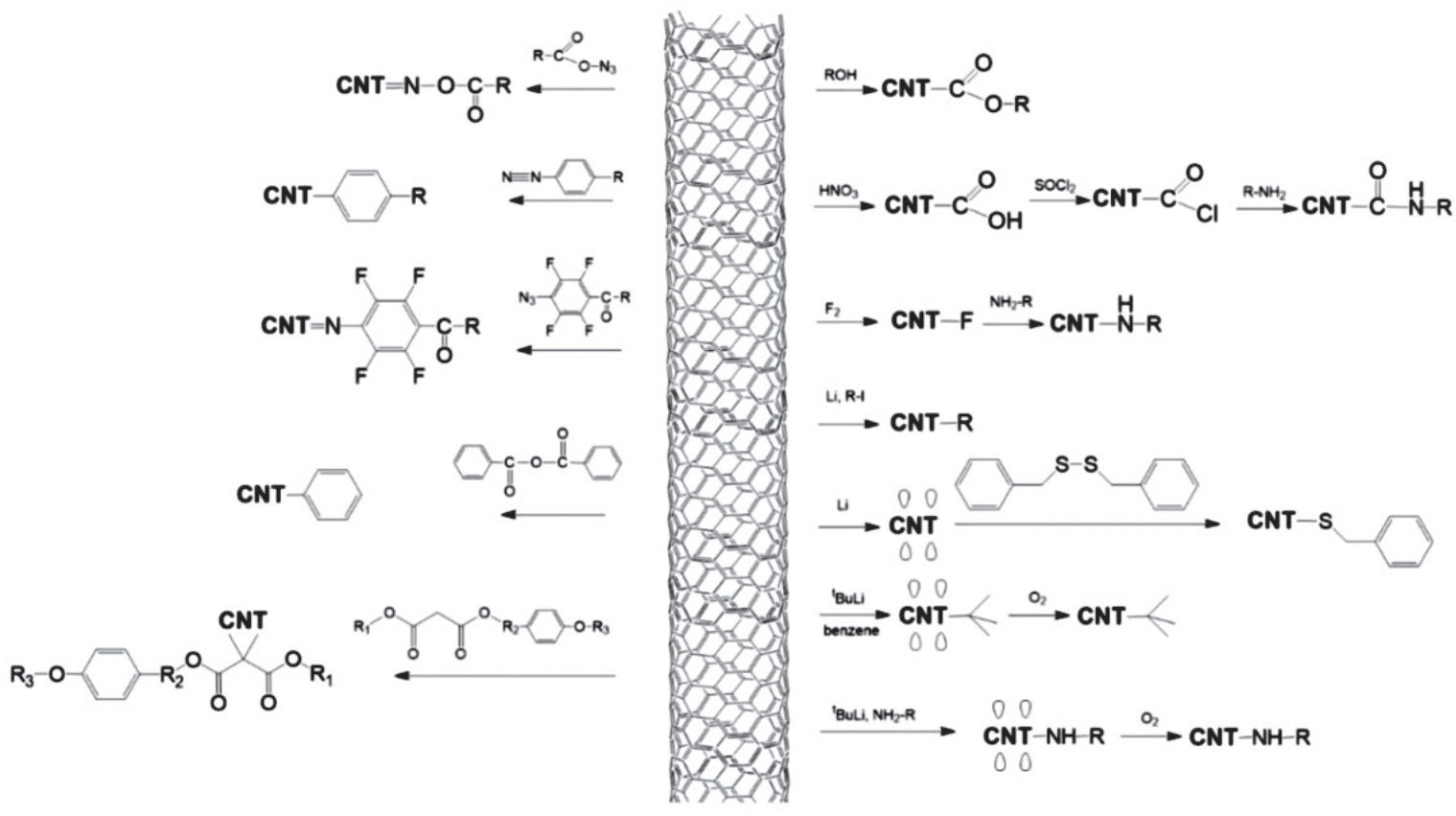

Figure 1. Scheme of the main approaches to covalent functionalization of SWCNTs. 
covalent functionalization of CNTs is widely used to increase the solubility of CNTs in solvents. ${ }^{[58-60]}$ Covalent functionalization of CNTs can be achieved by introducing chemical functional groups using different reaction including fluorination, radical chemistry, reductive alkylation and arylation (Billups reactions), Bingel reaction, reactions with diazonium, nitrene, dichlorocarbene compounds. Authors of the review ${ }^{[61]}$ provided a list of several covalent functionalization strategies. The most commonly used methods for functionalization of carbon nanotubes are shown in Figure 1. The covalent attachment of molecules is also carried out by click-chemistry or substitution reactions with the formation of amide, ether or peptide groups. Functionalization of single-wall carbon nanotubes via the addition of (R-)oxycarbonyl nitrenes was described by Holzinger and co-authors. ${ }^{[62]}$ The suggested approach allows binding of a variety of different groups such as alkyl chains, aromatic groups, dendrimers, and others. For example, perfluoroarylazide derivatives were used to modify carbon nanomaterials in order to attach hydrophobic fluorosubstituted aromatic molecules to their surfaces. ${ }^{[63,64]}$

\section{D Materials Based on Carbon Nanotubes}

Creation of new porous 3D carbon nanostructures cross-linked via different aromatic molecules is another important fundamental task of nanotechnology. To obtain such cross-linked structures, the same methods as for covalent functionalization of CNTs are used, but the aromatic molecule should contain two linking groups.

One of the methods used for the CNT binding is the Sonogashira coupling reaction, namely, the cross-coupling reaction of vinyl and aryl halides with terminal alkynes, catalyzed by palladium and copper. ${ }^{[65]}$ For instance, Kumar and Rao ${ }^{[66]}$ performed covalent binding of iodobenzene functionalized SWCNTs via 1,4-diethylbenzene and 4,4'-diethynyldiphenyl linkers by the Sonogashira reaction (Figure 2). The BrunauerEmmet-Teller (BET) surface areas of these assemblies were 742 and $788 \mathrm{~m}^{2} \cdot \mathrm{g}^{-1}$, respectively, while the pristine SWCNTs had a surface area of $400 \mathrm{~m}^{2} \cdot \mathrm{g}^{-1}$.

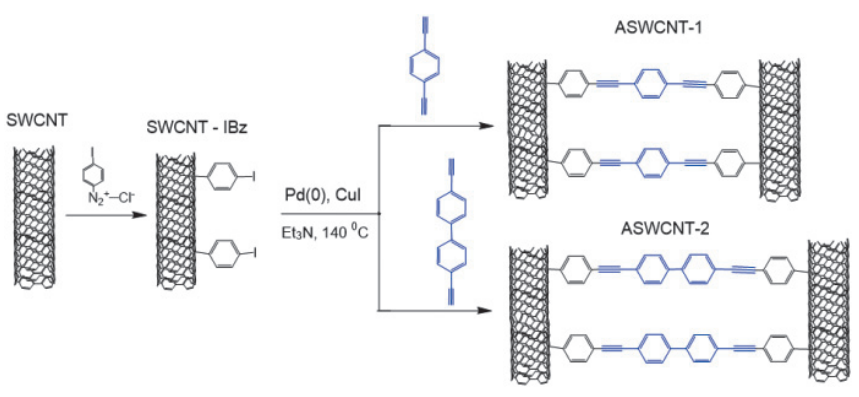

Figure 2. Preparation of 3D hybrids by the Sonogashira reaction.

Leonard et al..$^{[67]}$ prepared 3D carbon nanotube frameworks for hydrogen storage. Cross-linking was performed according to the reaction between terminally substituted amine linkers (methylenedianiline) and SWCNT fibers in the presence of oleum ( $20 \%$ free from $\left.\mathrm{SO}_{3}\right)$, sodium nitrite and 2,2'-azobis(2-methylpropionitrile) as shown in Figure 3.

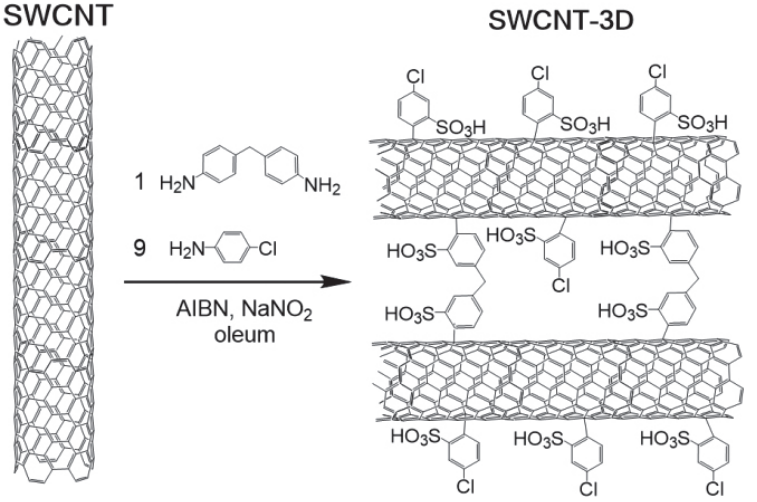

Figure 3. Cross-linking of SWCNTs using a methylenedianiline derivative.

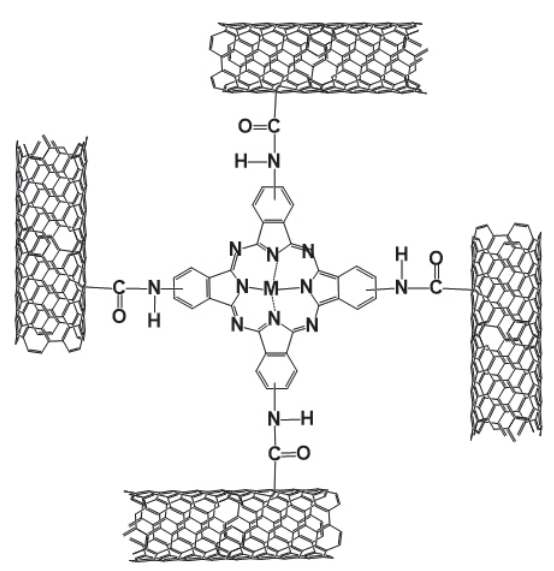

Figure 4. Cross-linking of SWCNTs via the formation of amide bonds. ${ }^{[40,41,68]}$

Nyokong and Mugadza obtained and investigated a series of 3D carbon nanomaterials with phthalocyanines of cobalt(II), ${ }^{[68]}$ iron(II) ${ }^{[40]}$ and nickel(II) ${ }^{[41]}$ The materials were synthesized by cross-linking of carbon nanotubes by tetrasubstituted MPc via the formation of amide bonds (Figure 4).

For this purpose, $\mathrm{COOH}$ groups of carboxylated SWCNTs were transformed to $\mathrm{COCl}$ by their treatment with thionyl chloride $\left(\mathrm{SOCl}_{2}\right)$ in anhydrous $\mathrm{DMF}$ at $70{ }^{\circ} \mathrm{C}$ for $24 \mathrm{~h}$. Then the obtained SWCNT-COCl was refluxed with tetraamino-substituted CoPc in DMF during $96 \mathrm{~h}$, and the resulting solid was centrifuged for $20 \mathrm{~min}$, washed with ethanol and dried under vacuum. In another work, ${ }^{[69]}$ SWCNTs, on the contrary, were functionalized by ethylenediamine groups and entered into the reaction with a cobalt phthalocyanine derivative bearing $\mathrm{COCl}$ groups $(\mathrm{CoTCOCl}$, Figure 5).

Ozden and co-workers ${ }^{[70]}$ used the well-known Suzuki cross-coupling reaction ${ }^{[71]}$ for the creation of $3 \mathrm{D}$ CNT networks. For this purpose, tetrakis(triphenylphosphine) palladium $\left(\mathrm{Pd}\left(\mathrm{PPh}_{3}\right)_{4}\right)$ was added to 1,4-phenyldiboronic acid and anhydrous $\mathrm{Cs}_{2} \mathrm{CO}_{3}$ in anhydrous toluene, followed by CNT-COCl, in argon atmosphere (Figure 6). The reaction mixture was heated at $100{ }^{\circ} \mathrm{C}$ for 5 days, and then the resulting material was filtered and washed with water to remove 
CoTCPc

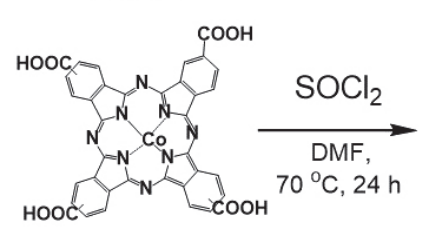

SWCNT

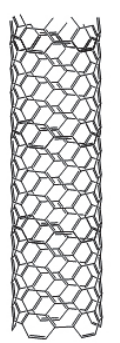

CoTCOCI

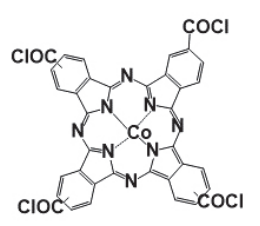

EA-SWCNT

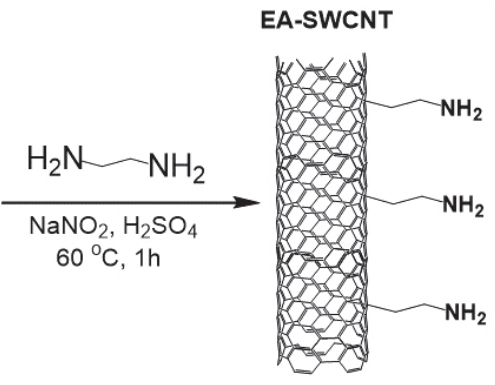

CoTCPC-EA-SWCNT (linked)
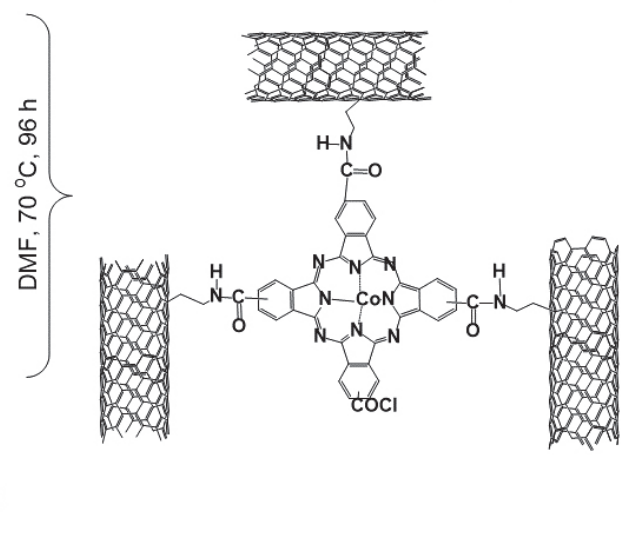

Figure 5. 3D hybrids based on SWCNTs and CoTCOCl.

CNT-COCl
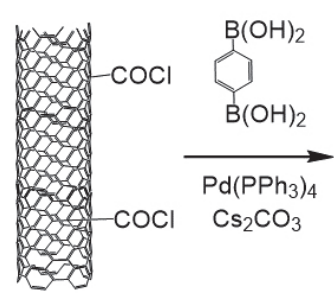

CNT-CO-Ph-CO-CNT

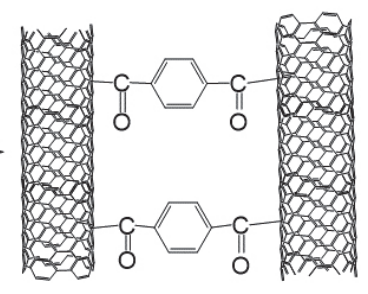

Figure 6. 3D CNT networks prepared according to the Suzuki cross-coupling reaction.

the excess of unreacted compounds. As a result, a carbon material with macrotubular architecture was obtained. CNT bundles were interconnected in a network, creating macroporous structures. It was determined by the BET surface analysis that the specific surface area of the obtained 3D CNT-based structure was $177 \mathrm{~m}^{2} \cdot \mathrm{g}^{-1}$. Despite this porous morphology, this value was not much higher than that of pristine CNTs $\left(166 \mathrm{~m}^{2} \cdot \mathrm{g}^{-1}\right)$.

De Marco et al. ${ }^{[72]}$ showed that 3D CNT hybrids could also be obtained by covalent linking of $p$-diiodobenzene and CNT by the addition of $\mathrm{Na}$ and naphthalene in $N, N$-dimethylacetamide (DMAc) as a solvent (Figure 7). $p$-Diiodobenzene was selected as a soluble, rigid, electrophilic cross-linking agent. The optimal metal concentration providing maximal debundling of CNTs and the grafting

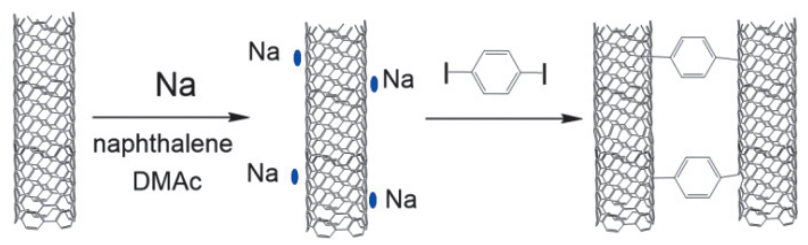

Figure 7. Scheme of the cross-linking of CNTs by the reaction with $p$-diiodobenzene. ratio of $17 \mathrm{wt} \%$ (determined by TGA) was shown to be $15 \mathrm{mM}$. The obtained 3D materials were found to have the enhanced specific surface area $\left(766 \mathrm{~m}^{2} \cdot \mathrm{g}^{-1}\right)$ estimated by $\operatorname{BET}\left(\mathrm{N}_{2}\right)$ measurements which is three times higher than in the case of pristine SWCNTs $\left(217 \mathrm{~m}^{2} \cdot \mathrm{g}^{-1}\right)$. The obtained materials had good electrical conductivity $\left(9.4 \mathrm{~S} \cdot \mathrm{m}^{-1}\right)$, low mass density $\left(2.3 \mathrm{mg} \cdot \mathrm{cm}^{-3}\right)$ and high chemical stability.

Schirowski et al. ${ }^{[73]}$ prepared 3D structures by the reaction between negatively charged potassium intercalated SWCNTs and bisdiazonium salts (benzene-4,4'bis(diazonium) or 1,1'-biphenyl-4,4'-bis(diazonium) salts) or diiodo compounds ( $p$-diiodobenzene or $p$-diiodobiphenyl) acting as electrophiles (Figure 8). It was shown that the functionalization of SWCNTs using diiodo compounds resulted in the better functionalization homogeneity and the higher degree of addend binding. The degree of functionalization

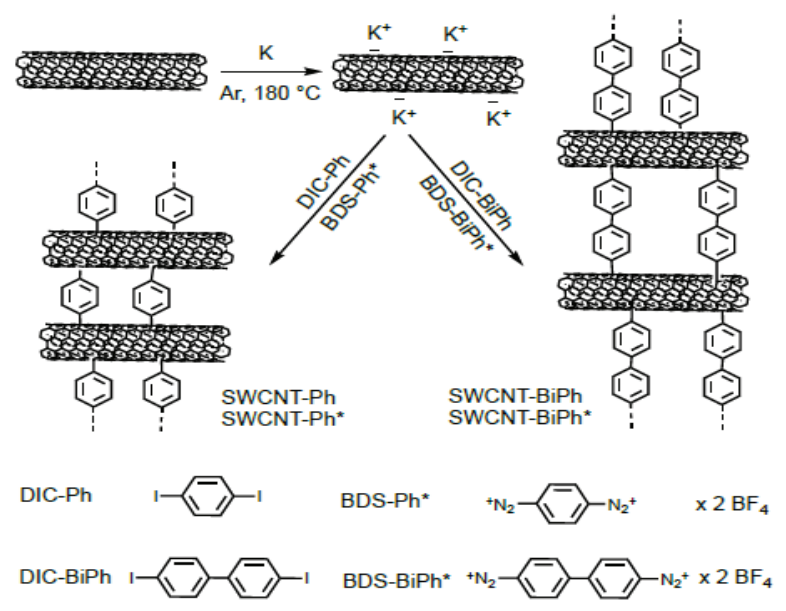

Scheme 1. Synthesis of biphenylene- and phenylene-linked SWCNTs via bisdiazonium salts (BDS) and diiodo compounds (DIC) starting from potassium nanotubides $\left(\mathrm{KC}_{4}\right)$.

Figure 8. Synthesis of biphenylene- and phenylene-linked SWCNTs via bisdiazonium salts and diiodo compounds. Reprinted with permission from the American Chemical Society, Copyright (2018) ${ }^{[73]}$ 
was higher in the case of phenylene linkers, while biphenylene linkers led to the higher surface area and better thermal stability. The authors also stated that the size of linkers, type of functionalization and its degree affected the macroscopic properties of the material. For example, SWCNTs crosslinked via biphenylene derivatives exhibited the $33 \%$ higher external surface and the better kinetics of oxygen reduction in comparison with SWCNTs bound via phenyl linkers.

In a series of our research group, 3D hybrid materials based on SWCNTs and various polyaromatic linking molecules, viz. pyrene, ${ }^{[74]}$ coumarin, ${ }^{[75,76]}$ BODIPY, ${ }^{[77]}$ and silicon phthalocyanine, ${ }^{[78]}$ were prepared and studied. The hybrids were synthesized according to the well-known reaction of "click chemistry", namely azide-alkyne Huisgen cycloaddition (Figure 9). Azide-modified SWCNT-N3 were prepared in the nitrogen atmosphere by the addition of SWCNTs $(0.4 \mathrm{mmol})$ to the mixture of $\mathrm{NaN}_{3}(6 \mathrm{mmol})$ and iodine monochloride $(1.5 \mathrm{mmol})$ in $25 \mathrm{~mL}$ of acetonitrile. SWCNTs modified with azide groups react with a linking molecule bearing two terminal alkyne groups in the presence of a $\mathrm{Cu}(\mathrm{I})$ catalyst formed in situ from copper(II) sulphate pentahydrate and sodium L-ascorbate.

An interesting unusual method for the preparation of 3D CNT structures was proposed by Jombert el al. ${ }^{[79]}$ Nanotubes were cross-linked by the ligand exchange reaction between cis- $\left[\mathrm{Pt}(\mathrm{dmso})_{2} \mathrm{Cl}_{2}\right]$ and pyridine-functionalized single walled carbon nanotubes (Py-SWCNT) (Figure 10). Platinum was confirmed by XPS to coordinate the pyridine nitrogen atoms. It was shown that this type of coordination did not have a significant effect on the conductance of PySWCNT films.

\section{Hybrid Materials as Active Layers of Chemiresistive Sensors}

\section{Hybrid Materials on the Basis of Carbon Nanotubes and Metal Phthalocyanines}

Electrical properties of SWCNTs are usually determined by their chirality, i.e. the angle of orientation of the graphite plane relative to the tube axis. ${ }^{[80,81]}$ The electrical conductivity of semiconductor SWCNTs can alter upon adsorption of various molecules on their surface due to the change in the concentration of charge carriers in SWCNTs. ${ }^{[3,82]}$ A prototype of the first sensor based on SWCNTs towards $\mathrm{NO}_{2}$ was described by Kong in 2000. ${ }^{[83]}$ Later other researchers ${ }^{[5]}$ found that thin SWCNT layers could be used to determine small (40-100 ppb) $\mathrm{NO}_{2}$ concentrations in dry air. To date, the sensor characteristics of pristine SWCNTs have been studied towards a number of gases such as $\mathrm{NH}_{3}, \mathrm{NO}_{2}, \mathrm{H}_{2}, \mathrm{CH}_{4}, \mathrm{CO}, \mathrm{H}_{2} \mathrm{~S}$, and $\mathrm{O}_{2}$, as well as volatile organic vapours (VOC).

Phthalocyanine derivatives are widely used for the improvement of SWCNT chemiresistive sensor properties due to their semiconductor behaviour and good sensor response to various gases. ${ }^{[84-88]}$ To date chemiresistive sensors on the basis of hybrid materials of CNTs with phtha-

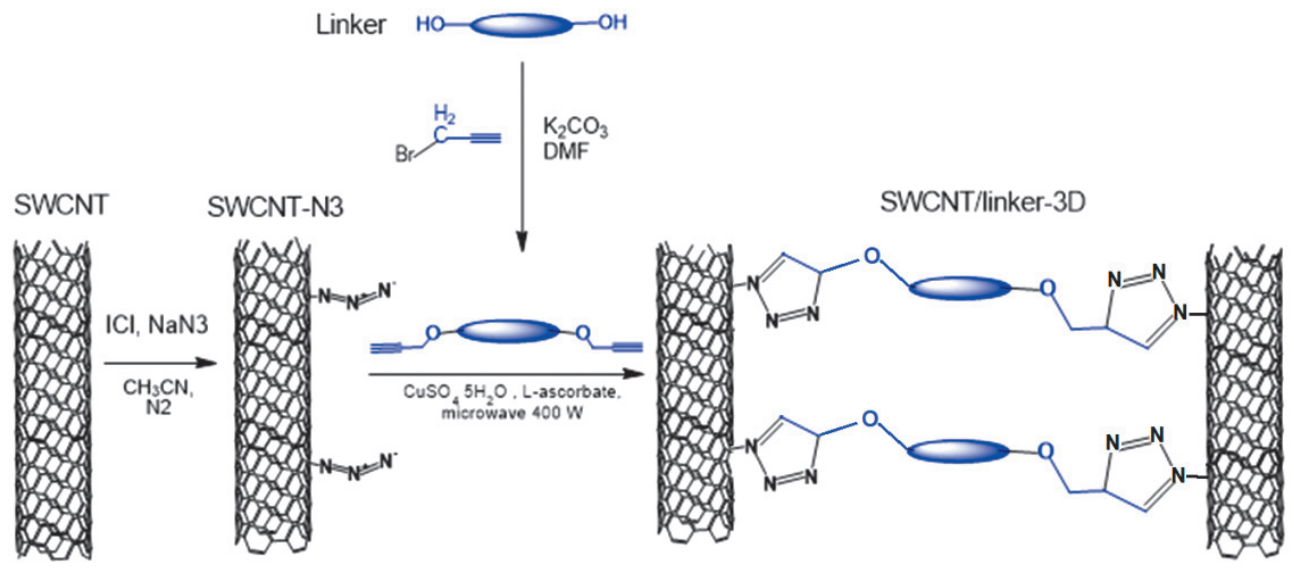

Figure 9. Scheme of the preparation of 3D hybrids by the reaction of azide-alkyne Huisgen cycloaddition.

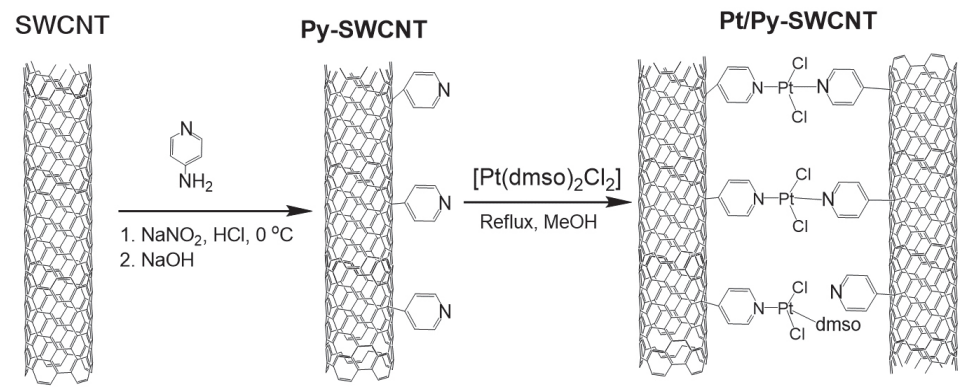

Figure 10. Scheme of the synthesis of SWCNTs cross-linked via a Pt complex. 
Table 1. Characteristics of hybrid sensor layers according to the data presented in Refs. ${ }^{[91,97,98]}$

\begin{tabular}{|c|c|c|c|c|c|c|c|c|c|c|c|}
\hline \multirow[b]{2}{*}{ Parameters } & \multicolumn{11}{|c|}{ Sensing Layers } \\
\hline & $\begin{array}{c}\text { SWCNT- } \\
\text { COOH }\end{array}$ & $\begin{array}{c}\text { MWCNT- } \\
\mathrm{COOH}\end{array}$ & $\begin{array}{c}\mathrm{PbPc} / \\
\text { SWCNT- } \\
\text { COOH }\end{array}$ & $\begin{array}{c}\mathrm{PbPc} / \\
\text { MWCNT- } \\
\text { COOH }\end{array}$ & SWCNT & $\begin{array}{c}\text { CuPcTTMP/ } \\
\text { SWCNT }\end{array}$ & $\begin{array}{l}\text { CuPcTIP/ } \\
\text { SWCNT }\end{array}$ & MWCNT & $\begin{array}{c}\mathrm{PbPc} / \\
\text { MWCNT }\end{array}$ & $\begin{array}{c}\text { NiPc/ } \\
\text { MWCNT }\end{array}$ & $\begin{array}{c}\mathrm{CuPc} / \\
\text { MWCNT }\end{array}$ \\
\hline Resistance, kOhm & $5-7 \cdot 10^{-2}$ & $0.4-0.5$ & $0.4-0.5$ & $16-20$ & $5-7 \cdot 10^{-2}$ & $0.2-0.3$ & $0.2-0.3$ & $0.4-0.5$ & - & - & $1.0-1.5$ \\
\hline $\mathrm{NH}_{3}$ conc., ppm & $0.15-80$ & $0.15-80$ & $0.15-80$ & $0.15-80$ & $0.15-80$ & $0.15-80$ & $0.15-80$ & $0.3-80$ & $0.3-80$ & $0.3-80$ & $0.3-80$ \\
\hline Response at $20 \mathrm{ppm}, \%$ & $\approx 13$ & $\approx 13$ & $\approx 16$ & $\approx 17$ & $\approx 14$ & $\approx 12$ & $\approx 15$ & $\approx 13$ & $\approx 13$ & $\approx 18$ & $\approx 25$ \\
\hline Recovery time at $20 \mathrm{ppm}, \mathrm{s}$ & $\approx 4000$ & $\approx 2000$ & $\approx 1500$ & $\approx 500$ & $\approx 3000$ & $\approx 250$ & $\approx 1000$ & $\approx 2000$ & - & - & $\approx 250$ \\
\hline LOD, ppb & - & - & 150 & 150 & - & - & - & - & - & - & 75 \\
\hline Ref. & [91] & [91] & [91] & [91] & [97] & [97] & [97] & [98] & [98] & [98] & [98] \\
\hline
\end{tabular}

locyanine derivatives have been widely studied in the literature, ${ }^{[89-96]}$ while the sensor properties of CNT/porphyrin hybrids have been described to a lesser extent. ${ }^{[20-23]}$

The literature analysis shows that a large number of works are devoted to the study of sensors towards ammonia. A group of Chinese scientists prepared hybrids of acid treated carbon nanotubes with $\mathrm{MPc}\left(\mathrm{M}=\mathrm{Pb},{ }^{[91]}\right.$ $\mathrm{Cu},{ }^{[97]} \mathrm{Ni},{ }^{[98]} \mathrm{Co}^{[99]}$ ) via non-covalent $\pi-\pi$-stacking interaction and studied their sensor properties towards ammonia. The researchers demonstrated that the hybrid materials $\mathrm{PbPc} / \mathrm{SWCNT}-\mathrm{COOH}$ and $\mathrm{PbPc} / \mathrm{MWCNT}-\mathrm{COOH}$ had the higher sensor response to $\mathrm{NH}_{3}$ than pristine carboxylated nanotubes (Table 1). They also showed the effect of the central metal on the sensor properties of investigated hybrids. ${ }^{[97-98]}$ The hybrids with CuPc possessed the higher response towards ammonia than those with $\mathrm{PbPc}$ and NiPc (Table 1).

Liang et al. ${ }^{[95]}$ prepared hybrid materials on the basis of MWCNTs and a number of tetrasubstituted phthalocyanines TFPMPc ( $\mathrm{M}=\mathrm{Co}, \mathrm{Zn}, \mathrm{Cu}, \mathrm{Pb}, \mathrm{Pd}$, and $\mathrm{Ni})$ bearing tetrafluoropropyloxy substituents. The materials were obtained by mixing solutions of MPc in dimethylformamide with a suspension of nanotubes during ultrasonic treatment at $50{ }^{\circ} \mathrm{C}$. Some sensor characteristics are given in Table 2. It was shown that the sensor response of TFPMPc/MWCNT layers to $\mathrm{NH}_{3}$ decreased in the following order: $\mathrm{Co}>\mathrm{Zn}>$ $\mathrm{Cu}>\mathrm{Pb}>\mathrm{Pd} \approx \mathrm{Ni}$. This experimental result was in good correlation with the DFT calculations of the value of charge transfer between the analyte and MPc molecule. The TFPMPc/MWCNT hybrids exhibited noticeably higher sensitivity to ammonia than to $\mathrm{CO}, \mathrm{CO}_{2}, \mathrm{H}_{2}, \mathrm{CH}_{4}$, and volatile organic compounds.
$\mathrm{Wu}$ et $a l_{.}{ }^{[99]}$ compared sensor properties of the layers of CoPcTc/MWCNT (CoPcTc is tetra- $\beta$ carboxyphthalocyaninatocobalt(II)) hybrid with the same hybrid mixed with ponyaniline (PANI) in the ration of 1:1. The last was shown to be the most sensitive to ammonia among the hybrids given in Table 2. The layer exhibited very fast recovery time (about 10 seconds at $20 \mathrm{ppm} \mathrm{NH}_{3}$ ) and low limit of detection (LOD) of $36 \mathrm{ppb}$.

Researchers from the groups of T. Basova and $\mathrm{M}$. Durmuş used SWCNT-based hybrids prepared by the methods of non-covalent ${ }^{[27,29,100-104]}$ and covalent ${ }^{[28]}$ functionalization, as well as 3D hybrids for the creation of active layers of chemiresistive sensors to ammonia. ${ }^{[78]}$ MPcs bearing long - $\mathrm{S}_{2}\left(\mathrm{CH}_{2} \mathrm{CH}_{2} \mathrm{O}\right)_{3} \mathrm{CH}_{3}$ chains and pyrene substituents were used for non-covalent functionalization of SWCNTs (Figure 11a,b). SWCNTs functionalized with MPc bearing $-\mathrm{S}\left(\mathrm{CH}_{2} \mathrm{CH}_{2} \mathrm{O}\right)_{3} \mathrm{CH}_{3}$ substituents gave fine stable dispersions in organic solvents, while pyrene substituents were introduced to improve $\pi-\pi$ interaction between phthalocyanine molecules and nanotube walls.

$\mathrm{ZnPc}$ shown in Figure 11c was utilized for both covalent and non-covalent functionalization of SWCNTs. The functionalization degrees of SWCNTs by different phthalocyanines, determined by TGA, and sensor characteristics are summarized in Table 3.

The functionalization degree of SWCNTs was shown to be a very important characteristic of hybrid materials with phthalocyanines, since the greater the degree of functionalization, the greater the sensor response. The method of covalent functionalization was found to lead to an increase in the functionalization degree by 1.5-2 times compared to the non-covalent one. The chemiresistive

Table 2. Characteristics of hybrid sensor layers according to the data presented in Refs. ${ }^{[95,99]}$

\begin{tabular}{|c|c|c|c|c|c|c|c|c|c|}
\hline \multirow[b]{2}{*}{ Parameters } & \multicolumn{9}{|c|}{ Sensing Layers } \\
\hline & MWCNT & $\begin{array}{l}\text { TFPNiPc/ } \\
\text { MWCNT }\end{array}$ & $\begin{array}{l}\text { TFPPdPc/ } \\
\text { MWCNT }\end{array}$ & $\begin{array}{l}\text { TFPPbPc/ } \\
\text { MWCNT }\end{array}$ & $\begin{array}{l}\text { TFPCuPc/ } \\
\text { MWCNT }\end{array}$ & $\begin{array}{l}\text { TFPZnPc/ } \\
\text { MWCNT }\end{array}$ & $\begin{array}{l}\text { TFPCoPc/ } \\
\text { MWCNT }\end{array}$ & $\begin{array}{c}\text { CoPcTc/ } \\
\text { MWCNT@ } \\
\text { PANI(1:1) }\end{array}$ & $\begin{array}{l}\text { CoPcTc/ } \\
\text { MWCNT }\end{array}$ \\
\hline $\mathrm{NH}_{3}$ conc., ppm & $0.1-200$ & $0.1-200$ & $0.1-200$ & $0.1-200$ & $0.1-200$ & $0.1-200$ & $0.1-200$ & $0.2-250$ & $0.2-250$ \\
\hline Response at $25 \mathrm{ppm}, \%$ & $\approx 9$ & $\approx 7$ & $\approx 9$ & $\approx 9$ & $\approx 14$ & $\approx 15$ & $\approx 18$ & $\approx 59$ & $\approx 22$ \\
\hline $\begin{array}{l}\text { Recovery time at } \\
20-25 \mathrm{ppm}, \mathrm{s}\end{array}$ & $\approx 700$ & $\approx 250$ & $\approx 300$ & $\approx 500$ & $\approx 250$ & $\approx 500$ & $\approx 500$ & $\approx 10$ & $\approx 250$ \\
\hline LOD, ppb & - & - & - & - & - & - & 60 & 36 & - \\
\hline Ref. & [95] & [95] & [95] & [95] & [95] & [95] & [95] & [99] & [99] \\
\hline
\end{tabular}



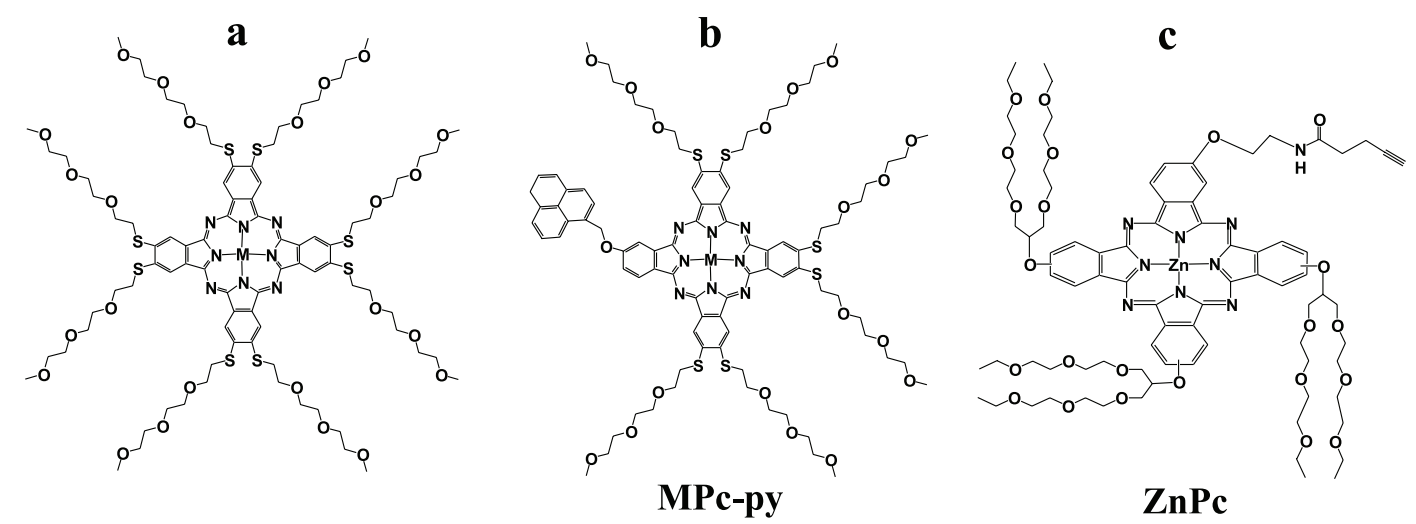

Figure 11. Structures of MPcs $(\mathrm{M}=\mathrm{Co}, \mathrm{Cu}, \mathrm{Zn}, 2 \mathrm{H})$ used for functionalization of SWCNTs in Refs. ${ }^{[28,29,101]}$

Table 3. Degree of functionalization $(\varphi)$ and sensor characteristics of SWCNTs modified with MPc molecules (Figure 11c).

\begin{tabular}{|c|c|c|c|c|c|c|c|c|}
\hline MPc & CuPc-py & CoPc-py & $\mathrm{H}_{2} \mathrm{Pc}-\mathrm{py}$ & $\mathrm{ZnPc}\left({ }^{+} \mathrm{Bu}\right)_{4}$ & $\mathrm{ZnNc}\left({ }^{\mathrm{t}} \mathrm{Bu}\right)_{4}$ & ZnPc (Fig. 11c) & ZnPc (Fig. 11c) & SiPc-3D \\
\hline Method & \multicolumn{6}{|c|}{ Non-covalent } & \multicolumn{2}{|c|}{ Covalent } \\
\hline$\varphi, \%$ & 0.54 & 0.36 & 0.22 & 0.36 & 0.64 & 0.30 & 0.52 & 1.75 \\
\hline$R_{H Y B} / R_{C N T}^{*}$ & - & - & - & 3.0 & 8.4 & 2.8 & 5.2 & 14.0 \\
\hline Recovery time, $\mathrm{s}$ & 60 & 30 & 40 & 30 & 40 & 70 & 70 & 200 \\
\hline Ref. & [29] & [29] & [29] & [27] & [27] & [104] & [104] & [78] \\
\hline
\end{tabular}

$* \mathrm{R}_{\mathrm{HYB}} / \mathrm{R}_{\mathrm{CNT}}$ is the ratio of sensor response of SWCNT/MPc hybrid to that of pristine SWCNTs towards 50 ppm of ammonia.

sensor response of the layers of SWCNTs covalently functionalized with $\mathrm{ZnPc}$ was noticeably higher than that of SWCNTs noncovalently functionalized by the same phthalocyanine (Figure 12).

It was also concluded that the introduction of an additional aromatic substituent ${ }^{[101]}$ or expansion of the aromatic system ${ }^{[27]}$ when passing from phthalocyanine $\mathrm{ZnPc}\left({ }^{(} \mathrm{Bu}\right)_{4}$ to naphthalocyanine $\mathrm{ZnNc}\left({ }^{\mathrm{t}} \mathrm{Bu}\right)_{4}$ complexes also causes an increase of the functionalization degree in the resulting

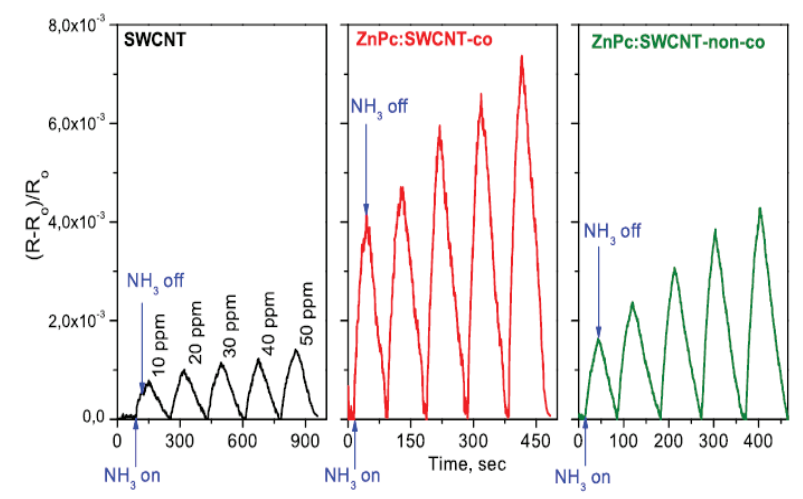

Figure 12. Sensor response of the layers of pristine SWCNTs and their hybrids obtained by covalent (ZnPc:SWCNT-co) and noncovalent (ZnPc:SWCNT-non-co) functionalization with $\mathrm{ZnPc}$ (Figure 11c) towards $\mathrm{NH}_{3}(10-50 \mathrm{ppm}$ ), measured in a dynamic regime at the constant Ar flow rate of $300 \mathrm{~mL} \cdot \mathrm{min}^{-1}$. Reprinted with permission from Elsevier S.A., Copyright (2017). ${ }^{[28]}$ hybrid materials and, as a consequence, an increase of their chemiresistive sensor response to ammonia.

Cross-linked carbon nanotubes, in which phthalocyanine molecules were used as linkers, were shown to be very attractive sensing materials for ammonia detection ${ }^{[78]}$ For instance, a 3D hybrid SWCNT/SiPc was obtained by the azide-alkyne cycloaddition (Click) reaction of azido-substituted SWCNTs with axially-bis(propynoxy) phthalocyaninatosilicon(IV) (SiPc) (Figure 13). The prepared hybrid nanomaterial exhibited completely reversible sensor responses to ammonia and hydrogen at room temperature; the recovery time was $100-200 \mathrm{~s}$ in the case of $\mathrm{NH}_{3}$ and $50-120 \mathrm{~s}$ in the case of $\mathrm{H}_{2}$ depending on gas concentrations. Due to its porous structure, the LOD values reached $0.5 \mathrm{ppm}$ and $70 \mathrm{ppm}$ for ammonia and hydrogen, respectively. SWCNT/SiPc was successfully used for the detection of both $\mathrm{NH}_{3}$ and $\mathrm{H}_{2}$ in the presence of $\mathrm{CO}_{2}$. On the contrary, $\mathrm{H}_{2} \mathrm{~S}$ was found to be an interfering gas for the $\mathrm{NH}_{3}$ detection.

CNT-based hybrid materials with phthalocyanines were also used for $\mathrm{H}_{2} \mathrm{~S}$ detection. Wu and co-authors ${ }^{[105]}$ prepared hybrid materials using acid treated multi-walled carbon nanotubes (aCNT) covalently bonded with cobalt(II) tetra- $\beta$-carboxyphenyloxyphthalocyanine $(\mathrm{cPcCo})$ via the condensation reaction in the presence of $N, N$-dicyclohexylcarbodiimide (DCC), using hydroquinone (HQ), $p$-aminophenol (PAP), and $p$-phenylenediamine (PPD) as linking molecules, which were named cPcCo-HQ-aCNT, cPcCo-PAP-aCNT and cPcCo-PPD-aCNT, respectively. Among the investigated hybrids (Figure 14) the $\mathrm{cPcCo}-$ HQ-aCNT layer demonstrated the highest sensor response

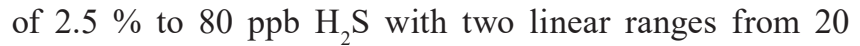



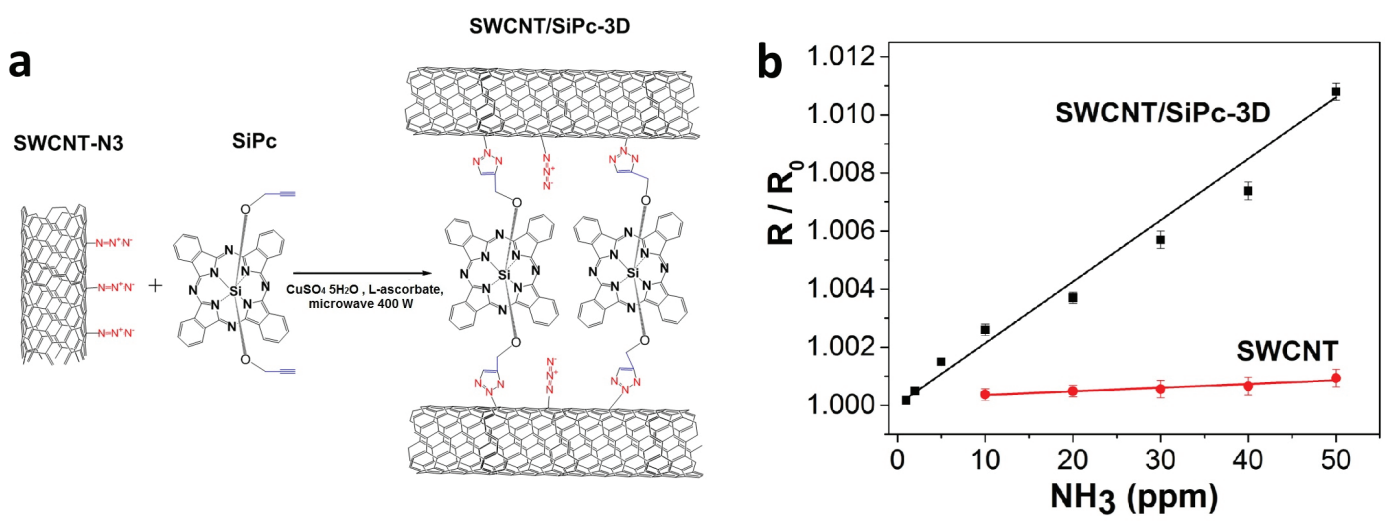

Figure 13. a: Scheme of the 3D hybrid SWCNT/SiPc; $\mathbf{b}$ : Dependence of the sensor response of a SWCNT/SiPc layer on $\mathrm{NH}_{3}$ concentration. ${ }^{[78]}$
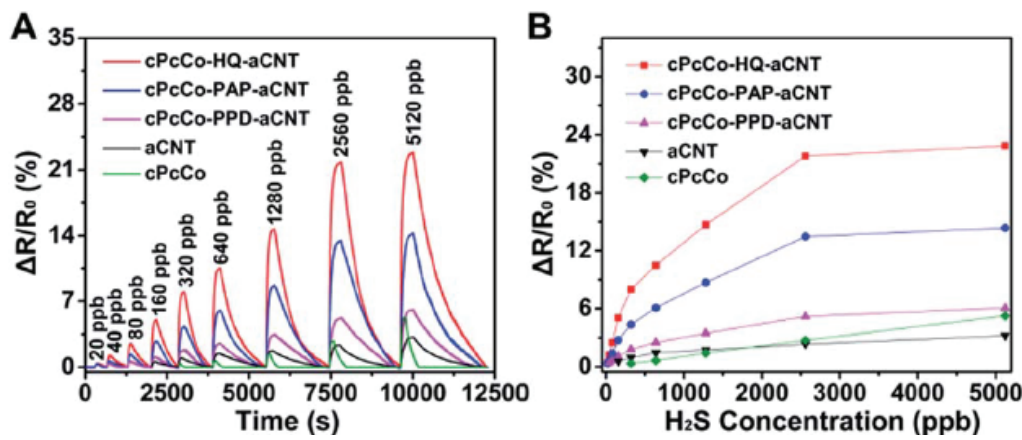

Figure 14. A: Response of cPcCo, aCNT, cPc-HQ-aCNT, cPcCo-PAP-aCNT and cPcCo-PPD-aCNT sensors to $\mathrm{H}_{2} \mathrm{~S}$; $\mathbf{B}$ : The dependence of the sensor response of cPcCo, aCNT, cPc-HQ-aCNT, cPcCo-PAP-aCNT and cPcCo-PPD-aCNT on $\mathrm{H}_{2} \mathrm{~S}$ concentration. Reproduced from Ref. ${ }^{[105]}$ with kind permission of Royal Society of Chemistry.

to $160 \mathrm{ppb}$ and from 320 to $2560 \mathrm{ppb}$, and a low detection limit of $5 \mathrm{ppb}$.

MPc/SWCNT hybrids can also be used for the detection of oxidizing gases like chlorine and $\mathrm{NO}_{2}$. There are several examples of hybrids obtained by noncovalent functionalization of carbon nanotubes in the literature, which were used for this purpose, among them carboxylated MWCNT with $\mathrm{Cu}$ (II) 2,3,9,10,16,17,23,24-octakis(octyloxy)-29H,31H phthalocyanine $\left(\mathrm{CuPcOC}_{8}\right),{ }^{[106,107]}$ carboxylated MWCNT with perfluorosubstituted $\mathrm{ZnPcF}_{16}{ }^{[108]}$ carboxylated SWCNT with $\mathrm{MPcF}_{16}(\mathrm{M}=\mathrm{Co}, \mathrm{Zn}){ }^{[109]}$ carboxylated SWCNT and MWCNT with $\mathrm{CuPcF}_{16}{ }_{16}{ }^{[10]} \mathrm{A}$ comparison of $\mathrm{CuPcF}_{16} /$ SWCNT-COOH (H1) and $\mathrm{CuPcF}_{16} / \mathrm{MWCNT}-\mathrm{COOH}(\mathrm{H} 2)$ hybrids showed that the sensor response to $\mathrm{Cl}_{2}$ was higher in the case of $\mathrm{H} 1$ layers (Figure 15). The detection limits for $\mathrm{H} 1$ and $\mathrm{H} 2$ hybrids were reported to be $0.27 \mathrm{ppb}$ and $0.85 \mathrm{ppb}$, respectively. ${ }^{[110]}$ In the case of $\mathrm{ZnPcF}_{16} /$ MWCNT- $\mathrm{COOH}^{[108]}$ the calculated LOD of $\mathrm{Cl}_{2}$ was even less and equal to $0.06 \mathrm{ppb}$.

The same group of authors ${ }^{[109]}$ compared the sensor response of carboxylated SWCNT functionalized with $\mathrm{CoPcF}_{16}, \mathrm{ZnPcF}_{16}$ and $\mathrm{CuPcF}_{16}$ and shown that their sensor response to $\mathrm{Cl}_{2}$ decreased in the order $\mathrm{CoPcF}_{16}>\mathrm{ZnPcF}_{16}$ $>\mathrm{CuPcF}_{16}$, indicating that the central metal ion played an important role in the sensitivity to $\mathrm{Cl}_{2}$ : the larger the ionic radius, the greater the charge transfer and $\mathrm{Cl}_{2}$ interaction with the sensing layer. The calculated LOD was $0.04 \mathrm{ppb}$ and $0.05 \mathrm{ppb}$ for $\mathrm{CoPcF}_{16} / \mathrm{SWCNT} \mathrm{COOH}$ and $\mathrm{ZnPcF}_{16} /$ SWCNT-COOH hybrids, respectively.

Volatile organic compounds can be also detected using sensing layers of CNT-based hybrids with metal phthalocyanines. Ndiaye et al. ${ }^{[2]}$ compared sensor properties of CNTs non-covalently modified with a phthalocyanine and porphyrins, viz. tetra-tert-butyl-29H,31H-phthalocyanine $\left(\mathrm{CuPc}^{\mathrm{t}} \mathrm{Bu}\right), \quad 2,3,7,8,12,13,17,18$-octaethyl-21H,23Hporphine $\left(\mathrm{OEPH}_{2}\right)$, and 5,10,15,20-tetraphenyl-21H,23Hporphine $\left(\mathrm{TPPH}_{2}\right)$, towards benzene, toluene and xylene. The amount of complexes adsorbed on CNTs estimated by TGA was maximal in the case of the hybrid with $\mathrm{CuPc}^{\mathrm{t}} \mathrm{Bu}$. The chemiresistive sensor responses of the hybrid materials were compared with those measured by a quartz crystal microbalance technique (QCM) (Table 4). It was shown that the maximal response to toluene, measured by both methods, was registered for $\mathrm{CNT} / \mathrm{CuPc}^{\mathrm{B}} \mathrm{Bu}$ layers. Similarly to the data obtained in works ${ }^{[27-29]}$ the maximal sensor response was observed for the hybrids with the higher degree of functionalization.

Wang et al. ${ }^{[92]}$ prepared and investigated the SWCNT/ CoPc hybrid exhibiting good selectivity and high sensor response to dimethyl methylphosphonate vapours $(0.5-40 \mathrm{ppm})$. The hybrid was obtained via noncovalent functionalization of SWCNTs by tetrasubstituted cobalt 


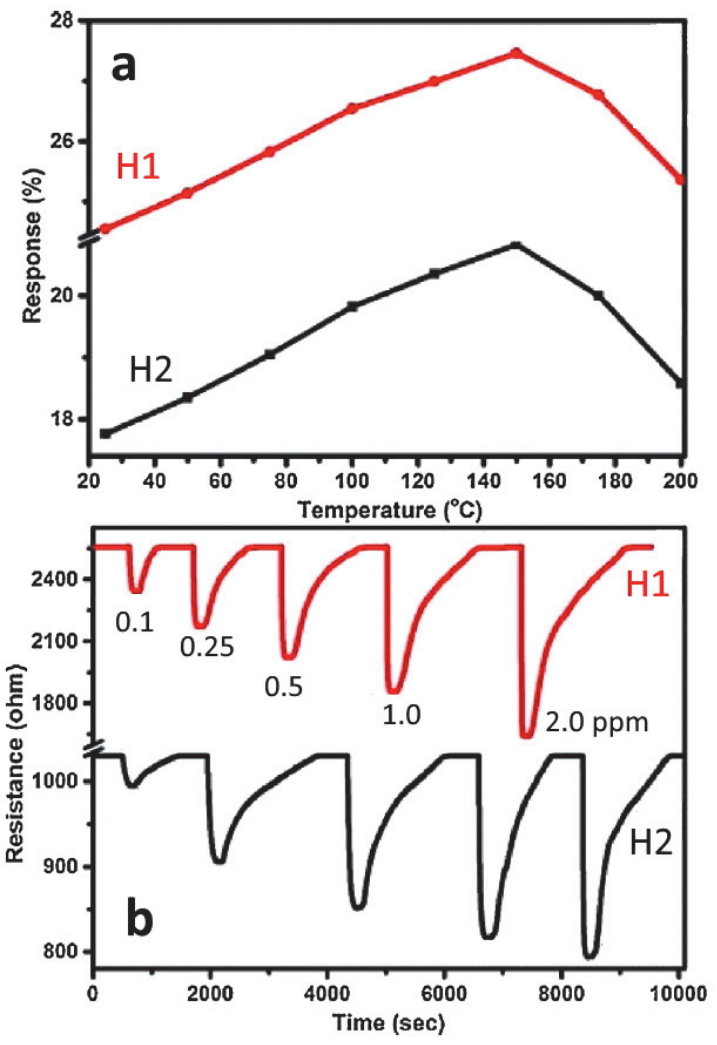

Figure 15. a: Sensor response of $\mathrm{CuPcF}_{16} / \mathrm{SWCNT}-\mathrm{COOH}$ (H1) and $\mathrm{CuPcF}_{16} / \mathrm{MWCNT}-\mathrm{COOH}(\mathrm{H} 2)$ hybrids to $1 \mathrm{ppm}$ of $\mathrm{Cl}_{2}$ as a function of temperature; $\mathbf{b}$ : the typical resistance-time characteristics of $\mathrm{H} 1$ and $\mathrm{H} 2$ sensors for different concentrations of $\mathrm{Cl}_{2}(0.1-2 \mathrm{ppm})$ at $150{ }^{\circ} \mathrm{C}$. Redrawn from Ref. ${ }^{[110]}$ phthalocyanine (Figure 16a). The mole rate of $\mathrm{CoPc}$ in the hybrid material was $0.42 \%$. The higher sensitivity of the hybrid layers to dimethyl methylphosphonate vapors than that of pristine SWCNTs (Figure 16b) was explained by the formation of hydrogen bonds between the dimethyl methylphosphonate molecule and fluorine-containing substituents in CoPc macrocycle.

\section{Hybrid Materials on the Basis of Carbon Nanotubes and Other Polyaromatic Molecules}

Apart from metal phthalocyanines other polyaromatic molecules are also widely used for the preparation of CNTbased hybrid materials. Calixarenes are very attractive compounds for the application in gas sensing using QCM and optical methods, ${ }^{[11]}$ however their low conductivity prevents the creation of chemiresistive sensors. Preparation of hybrids on the basis of CNT and calixarenes allows overcoming this obstacle. Sarkar et al. ${ }^{[37,112,113]}$ demonstrated that the formation of SWCNT/calixarene hybrids can be achieved due to the strong interaction between the SWCNTs and aromatic rings of calixarene. Calixarenes are characterized by a bowl-shaped structure with a cavity that has a hydrophobic pendent and the ability to adapt to changes from a close to flat conformation when interacting with analyte molecules. Consequently, the sensitivity of the sensor can be adjusted by manipulating the calixarene-analyte interaction by selecting the appropriate type of calixarene that has a different cavity size and/or different terminal functional groups.

Table 4. Mass and chemiresistive sensor responses of the sensing layers towards toluene (according to the data of Ref. ${ }^{[22]}$ ).

\begin{tabular}{ccccccc}
\hline & \multicolumn{3}{c}{ Mass sensor responses $\cdot 10^{3},{\mathrm{~Hz} \cdot \mathrm{ng}^{-1}}$} & \multicolumn{3}{c}{ Resistive sensor responses $\cdot 10^{3}\left(\Delta \mathrm{R} / \mathrm{R}_{0}\right)$} \\
\cline { 2 - 7 } Sensor Layers & $150 \mathrm{ppm}$ & $430 \mathrm{ppm}$ & $1200 \mathrm{ppm}$ & $150 \mathrm{ppm}$ & $430 \mathrm{ppm}$ & $1200 \mathrm{ppm}$ \\
\hline $\mathrm{CNT}$ & $\mathrm{NS}$ & $\mathrm{NS}$ & $\mathrm{NS}$ & $\mathrm{NS}$ & $\mathrm{NS}$ & $\mathrm{NS}$ \\
$\mathrm{CNT} / \mathrm{CuPc} \mathrm{Bu}$ & 2.11 & 3.50 & 4.5 & 2.5 & 5.6 & 15.1 \\
$\mathrm{CNT} / \mathrm{OEPH}_{2}$ & 1.55 & 3.04 & 4.0 & 2.0 & 3.5 & 7.1 \\
$\mathrm{CNT} / \mathrm{TPPH}_{2}$ & 1.35 & 2.50 & 3.7 & 0.1 & 0.9 & 4.1 \\
\hline
\end{tabular}

$\mathrm{NS}=$ not stable response

a

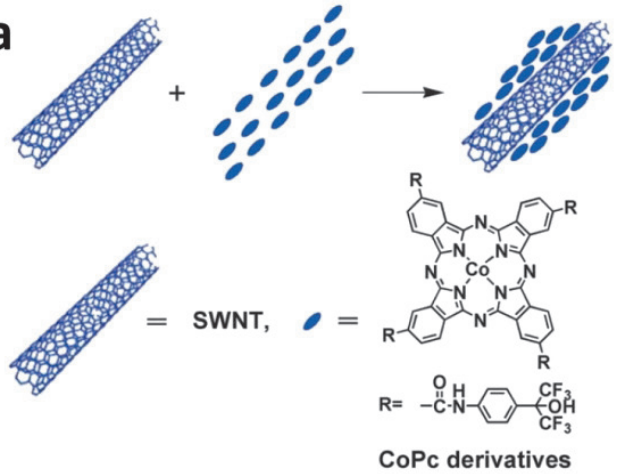

b

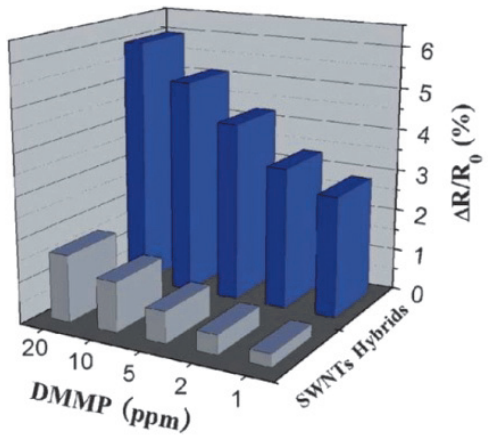

Figure 16. a: Structural formula of CoPc and scheme of noncovalent functionalization of carbon nanotubes; $\mathbf{b}$ : Dependence of the sensor response of pristine carbon nanotubes and SWCNT/CoPc hybrid on the concentration of dimethyl methylphosphonate. Reproduced from Ref. ${ }^{[92]}$ with kind permission of Royal Society of Chemistry. 
The chemiresistor was fabricated by dielectrophoretic alignment of carboxylated SWCNTs on interdigitated gold microelectrodes followed by functionalization of SWCNTs with calixarene (Figure 17) by a solvent casting technique. The prepared electrodes were used for the detection of benzene, toluene, ethylbenzene and xylene vapors and exhibited LOD of $25,7.5,6.5$ and 4 ppm, respectively. ${ }^{[37]}$ The same SWCNT/calixarene hybrid was shown to exhibit the limit

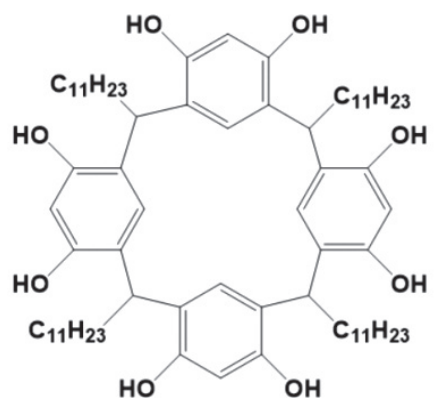

Figure 17. Structure of calix[4]resorcinarene used for the preparation of chemiresistors. ${ }^{[37,112,113]}$
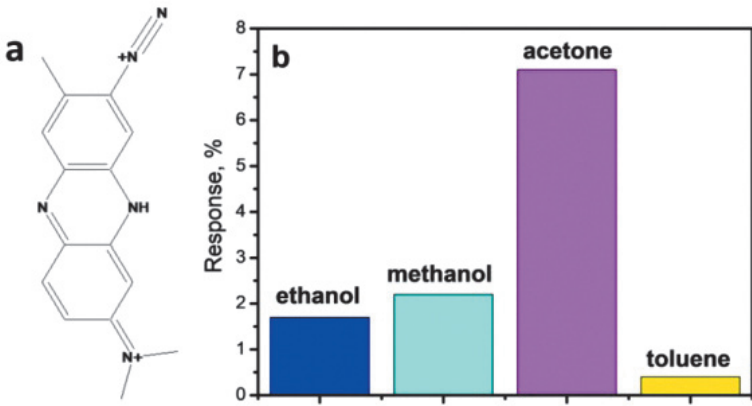

Figure 18. a: Structure of the Neural Red dye diazonium salt (NR); b: Selectivity histogram of the CNT NR hybrid. Drawn according to the data presented in Ref. ${ }^{[115]}$

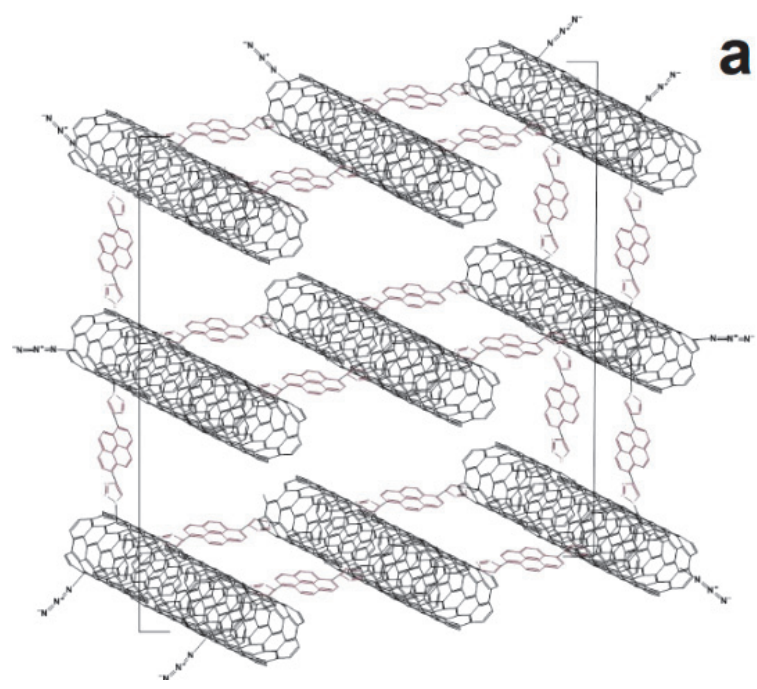

\section{a}

of detection of $\sim 0.6 \mathrm{ppm}, \sim 0.3 \mathrm{ppm}$ and $\sim 0.4 \mathrm{ppm}$ for $\mathrm{NH}_{3}$, trimethylamine and dimethylamine, respectively, ${ }^{[112]}$ and $25 \mathrm{ppb}$ for $\mathrm{NO}_{2} \cdot{ }^{[113]}$

Wei et al. ${ }^{[114]}$ reported about the preparation of 1-pyrenemethylamine functionalized SWCNTs for the active layers of a chemiresistive sensor for the detection of 2,4,6-trinitrotoluene in deionized water at ppt concentration level. Amino substituents in 1-pyrenemethylamine molecules attached to SWCNTs via $\pi-\pi$ interaction selectively interact with trinitrotoluene with the formation of negatively charged complexes, which cause the conductivity change of the hybrid sensing layer.

Bensghaïera et $a l^{[115]}$ reported the functionalization of CNTs by the Neural Red dye diazonium salt (NR, Figure 18) through diazonium interface chemistry for the development of chemiresistive sensors towards acetone. It was shown that the Neural Red dye diazonium salt reacted spontaneously with the formation of C-C bonds with MWCNTs in water at room temperature.

The layers of the CNT-NR hybrid drop casted onto glass substrates with predeposited gold electrodes were used for the detection of different volatile organic compounds (ethanol, methanol, acetone and toluene). The layers were shown to exhibit highly selective sensor response towards $1000 \mathrm{ppm}$ of acetone with the response/recovery time of 47 and $49 \mathrm{~s}$ at room temperature. Their selectivity to acetone was driven by the interaction between the $\mathrm{N}$ atom of electron donating dimethylamino groups of NR and electron deficient carbon atom in the $\mathrm{C}=\mathrm{O}$ group of acetone.

Polyaromatic molecules can be also used as linking molecules for the creation of 3D structures of cross-linked carbon nanotubes. These structures were shown to have porous structure and developed surface area, which is important for the creation of chemiresistive sensors with high sensitivity. For example, Şenocak et al. ${ }^{[74]}$ prepared a SWCNT-Pyrene 3D hybrid material (Figure 19a) by the reaction of "Click chemistry" between SWCNTs functionalized with azide groups and 1,6-diethynylpyrene. The SWCNT-Pyrene 3D hybrid material exhibited completely reversible sensor towards low concentrations of ammonia (0.1-40 ppm) at

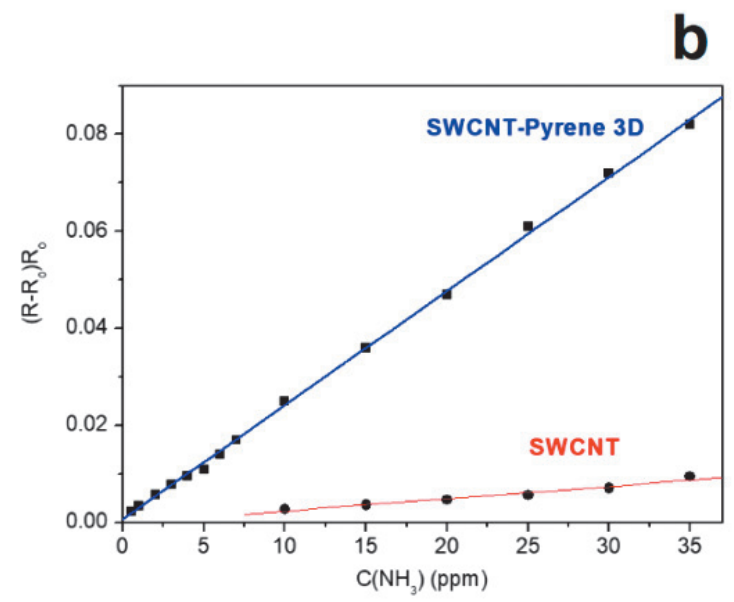

Figure 19. a: Structure of SWCNT-Pyrene 3D hybrid; b: Dependence of the sensor response of the films of SWCNT-Pyrene 3D and pristine SWCNT on ammonia concentration. Reproduced from Ref. ${ }^{[74]}$ with kind permission of Elsevier S.A. 
room temperature, which was noticeably higher than that of pristine SWCNTs. The surface area of the SWCNT-Pyrene 3D hybrid was shown by the Brunauer-Emmett-Teller (BET) method ${ }^{[74]}$ to increase from $835 \mathrm{~m}^{2} \mathrm{~g}^{-1}$ to $991 \mathrm{~m}^{2} \mathrm{~g}^{-1}$ compared to pristine carbon nanotubes. LOD of SWCNT films was found to be $10 \mathrm{ppm}$ while that of the $3 \mathrm{D}$ hybrid was $0.5 \mathrm{ppm}$.

Polyakov et al. ${ }^{[76]}$ studied the effect of different types of functionalization of SWCNTs by 3-phenylcoumarin derivatives on the chemiresistive sensor response to ammonia. First two hybrids were prepared by the "Click" reaction between SWCNTs modified with azido groups and 7-propinyloxy-3-( $p$-propinyloxyphenyl)coumarin bearing two terminal alkyne groups (SWCNT/PhC2-3D) or with 7-propinoxy-3-(3',4',5'-trimethoxyphenyl)coumarin bearing one terminal alkyne group (SWCNT/PhC1cov) (Figure 20). The third hybrid material was prepared by noncovalent functionalization of SWCNTs, namely by adsorption of 7-propinyloxy-3-( $p$-propinyloxyphenyl) coumarin on SWCNT surface (SWCNT/PhC2-noncov). It was shown that the sensor response to ammonia increased in the order SWCNT/PhC2-noncov $<\mathrm{SWCNT} / \mathrm{PhC1-cov}$ $<$ SWCNT/PhC2-3D and was in good correlation with the amount of coumarin molecules attached to the surface of carbon nanotubes.

\section{Hybrid Materials for Modification of Electrodes of Electrochemical Sensors}

\section{Hybrid Materials Based on Carbon Nanotubes and Metal Phthalocyanines for Modification of Electrodes of Electrochemical Sensors}

CNTs were shown to improve the electron transfer rate when used for electrode modification, and even exhibit elec- trocatalytic properties in some electrochemical processes. CNTs can cause a decrease in overpotentials and surface fouling on electrodes as well as an increase in voltammetric signals. ${ }^{[6]}$ On the other hand, metal phthalocyanines and related compounds are widely used as electron transfer mediators in electrochemical reactions and demonstrate electrocatalytic properties. ${ }^{[16,117]}$ Metal phthalocyanines adsorbed onto the surface of CNTs was shown to retain their catalytic properties. ${ }^{[26]}$

The literature abounds with various examples of obtaining hybrid materials based on carbon nanotubes and metal phthalocyanines and their application to modify the electrodes of electrochemical sensors, including review articles. ${ }^{[118]}$ However, since this date, there has been a noticeable increase in the number of registered methods. The modified electrodes were manufactured primarily for the preparation of biosensors for drug detection and clinical purposes. In this chapter, we present examples of electrochemical sensors based on such hybrid materials obtained over the past decade, focusing on methods for the preparation of such hybrid materials and modification of electrodes of electrochemical sensors.

In some studies, carbon nanotubes are first covalently or noncovalently functionalized with phthalocyanines, and then the resulting hybrids are used to modify the electrode surface, ${ }^{[43,119]}$ while in most cases, the electrodes are first modified with carbon nanotubes, and then the MPc solution is dropped on the top of the carbon layer, followed by drying ${ }^{[120,121]}$ or the electrode is immersed in the MPc solution. ${ }^{[122]}$ These methods are called "drop dry" or "dip dry" and are based on simple intermolecular forces, viz. electrostatic and $\pi-\pi$ interactions. In many other works, ${ }^{[123,124]}$ hybrid materials are obtained by mechanical mixing of CNT and MPc powders during their grinding in oil, and then this mixture is used to modify the electrodes. Some examples of the application of CNT/MPc hybrid
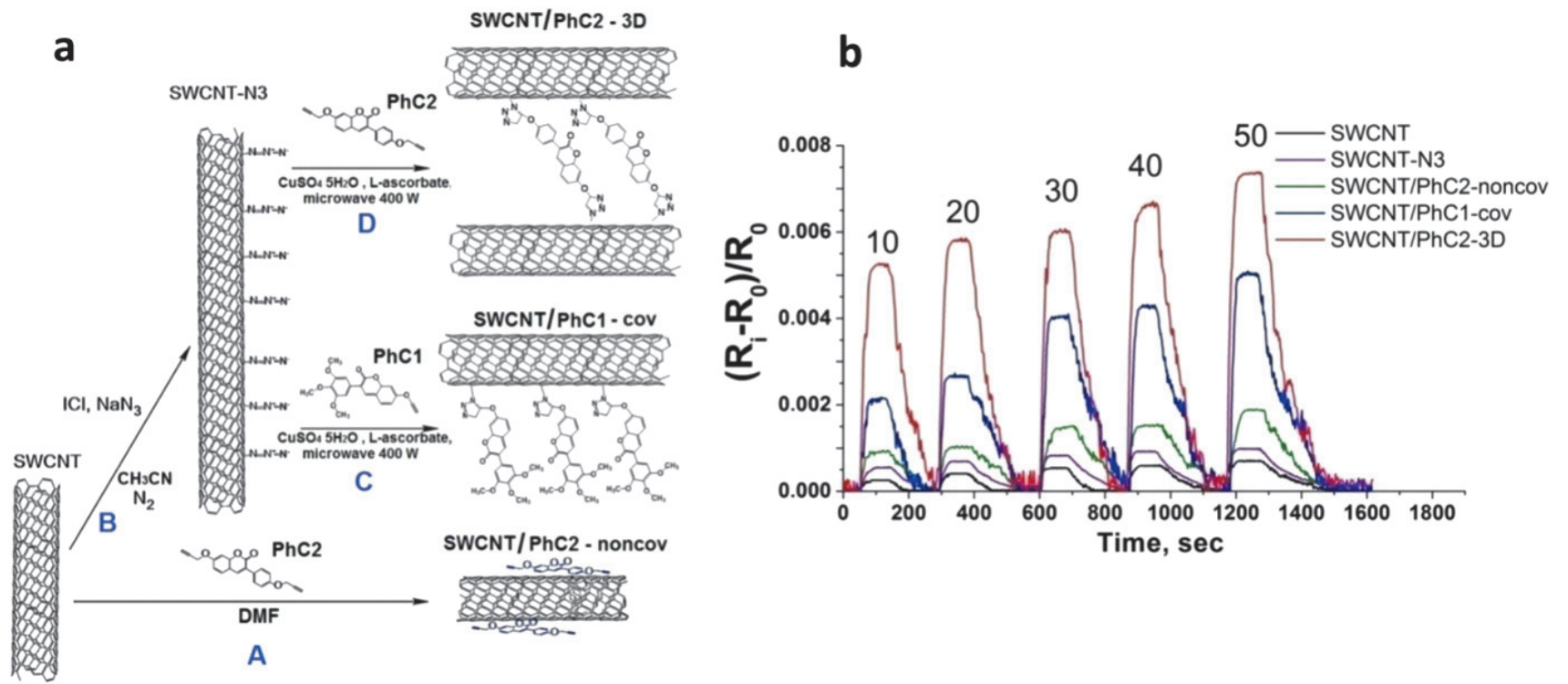

Figure 20. a: Scheme of the synthesis of hybrids material of SWCNT with 3-phenylcoumarin derivatives; b: Relative sensor response of the layers of pristine SWCNTs, azide-modified SWCNT-N3 and their hybrids towards $\mathrm{NH}_{3}(10-50 \mathrm{ppm})$. Reproduced from Ref. ${ }^{[76]}$ with kind permission of Elsevier S.A. 
materials for modification of electrodes of electrochemical sensors from the works published over the past 10 year are given in Table 5 .

It is known that the redox potentials of phthalocyanines can be more or less shifted anodically or cathodically depending on the type of substituents, axial ligands and central metal ions. Literature analysis shows that phthalocyanines containing redox active metal centres are mainly used as electron mediators in hybrid systems, e.g. phthalocyanines of cobalt, copper, manganese and iron. Unsubstituted metal phthalocyanines are often utilized for the preparation of hybrid materials due to their availability and ease of synthesis. They have low solubility in organic solvents, for this reason their hybrid materials are usually prepared by noncovalent functionalization of carbon nanotubes via mixing of the suspension of carbon nanotubes and MPcs in DMF or acetonitrile under ultrasonic treatment. ${ }^{[43,119,124]}$ Another method of the preparation of CNT-based hybrids is mechanical mixing of CNT and MPcs in the presence of oil or polymers (e.g. polypyrrole ${ }^{[125]}$ ). For example, Patrascu et $a l .{ }^{[123]}$ mixed MWCNT with FePc (1\%) in paraffin oil in a mortar. The electrode modified with this mixture was used to determine dopamine by cyclic voltammetry and differential pulse voltammetry. The detection limit of dopamine in water media was $2.05 \cdot 10^{-7} \mathrm{M}$. Electrodes modified with a composite material consisting of solid paraffin (mp $\left.55^{\circ} \mathrm{C}\right)$, MWCNT and unsubstituted CoPc mixed in a mortar were used to determine epinephrine (EP) in water and human urine samples. The detection limit in pure water was $15.6 \mathrm{nmol} \cdot \mathrm{L}^{-1}\left(2.86 \mu \mathrm{g} \cdot \mathrm{L}^{-1}\right) \cdot{ }^{[94]}$

Zuo et al. ${ }^{[126]}$ proposed another way to modify carbon nanotubes, which allows overcoming the low solubility of phthalocyanine. In their work, the CoPc-MWCNTs were synthesized in situ through tetramerization of dicyanobenzene on the surface of MWCNTs in the presence of $\mathrm{CoCl}_{2}$ and DBU (1,8-diazabicycloundec-7-ene) in $n$-pentanol. The mixture was stirred at $170{ }^{\circ} \mathrm{C}$ under nitrogen for $2 \mathrm{~h}$, then filtered, washed with ethanol and dried under vacuum. A glass carbon electrode (GCE) was modified by dropping CoPcMWCNT suspension in ethanol and used for the detection of ascorbic acid in the range from $1.0 \cdot 10^{-5} \mathrm{M}$ to $2.6 \cdot 10^{-3} \mathrm{M}$. The limit of detection was $1.0 \cdot 10^{-6} \mathrm{M}$.

Tetrasulfonated metal phthalocyanines $\left(\mathrm{MPc}\left(\mathrm{SO}_{3} \mathrm{H}\right)_{4}\right)$ are also widely used as electron mediators in electrochemical sensors. Due to their solubility in water their hybrid materials are prepared by mixing their water solutions with CNT dispersions in water. ${ }^{[42,127-129]}$ Karuppiah et al..$^{[42]}$ reported a simple sonochemical method to functionalize MWCNTs with nickel tetrasulfonated phthalocyanine, in which $\mathrm{NiPc}\left(\mathrm{SO}_{3} \mathrm{H}\right)_{4}$ also served as a dispersing agent for the MWCNTs via $\pi-\pi$ interactions.

Phthalocyanines bearing more complicated substituents are also utilized for the preparation of hybrid materials by noncovalent functionalization of carbon nanotubes for their further application for electrodes modification. For example, electrodes modified with MWCNT-based hybrids with 4-aminophenoxy- ${ }^{[130]}$ 4-oxy-3-methoxyphenylacrylic acid-[131] and 4-trifluoromethylphenoxy-substituted ${ }^{[132]}$ phthalocyanines (Figure 21) were used for the detection of $\mathrm{H}_{2} \mathrm{O}_{2}$, bisphenol A and nitrite, respectively (Table 5).

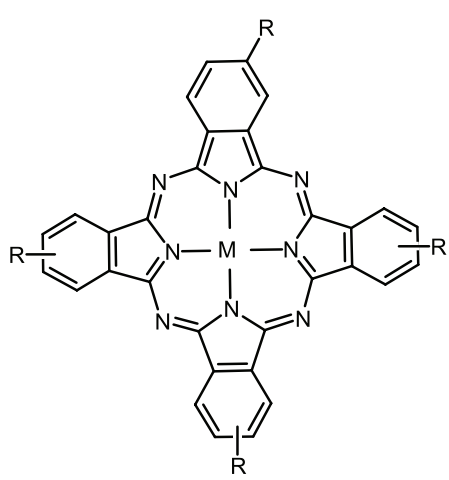

$\mathrm{R}:$

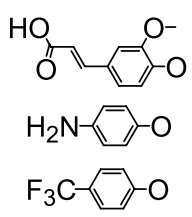

Figure 21. Examples of tetrasubstituted metal phthalocyanines used for the preparation of MWCNT-based hybrids. ${ }^{[130-132]}$

CNT-based hybrid materials covalently modified with MPc derivatives are also of great interest for the modification of glass carbon electrodes. Covalent attachment of phthalocyanines to SWCNTs via formation of amide bonds is a quite popular method of covalent functionalization. For example, tetraaminosubstituted nickel phthalocyanine $\left(\mathrm{NiPc}\left(\mathrm{NH}_{2}\right)_{4}\right)$ was shown to be covalently linked with SWCNTs modified with $\mathrm{COCl}$ groups with the formation of a $3 \mathrm{D}$ hybrid. ${ }^{[41]}$ The prepared hybrid offered a distinct advantage, giving the higher current response at lower oxidation overpotentials to 2-mercaptoethanol compared to the electrode modified with a mixture of $\mathrm{NiPc}\left(\mathrm{NH}_{2}\right)_{4}$ and SWCNTs, and a low detection limit reaching $0.15 \mathrm{M}$. In the work, ${ }^{[135]}$ carbon nanotubes, on the contrary, were modified with phenylamine groups and introduced into the reaction with $\mathrm{CoPc}$ bearing four $\mathrm{COCl}$ substituents. This hybrid was used to modify a GCE for the sensor towards diuron. The same CoPc was also used as a linker for the cross-linking of SWCNTs modified with ethylene amine groups, which were used to modify a glassy carbon electrode for its application for electrochemical detection of amitrole. ${ }^{[69]}$

One more hybrid was prepared by reaction between Co(II) phthalocyanine tetrasulfonyl chloride and SWCNTs modified with $\mathrm{CONHCH}_{2} \mathrm{CH}_{2} \mathrm{NH}_{2}$-groups ${ }^{[136]}$ (Figure 22) in the presence of aniline. Screen-printed graphite electrodes (SPEs) modified with the prepared hybrid were shown to be used for the low-potential electrochemical oxidation of thiocholine. The linear range for thiocholine detection was $0.077-0.45 \mathrm{mM}$, while the LOD was $0.038 \mathrm{mM}$.

One more promising method of the preparation of hybrid structures is layer by layer ( $\mathrm{LbL}$ ) electrostatic assembly. In this method, the multilayered structures were fabricated directly by alternately assembling of negatively charged acid treated carbon nanotubes and cationic cobalt(II) tetra- $\beta$-( $N, N, N$-trimethylaminoethoxy)phthalocyanine (Figure 23). ${ }^{[137]}$ The electrode modified in this way was revealed to exhibit good reproducibility, stability, and selectivity when detecting 4-nitrophenol in the presence of $\mathrm{NaNO}_{2}$, resorcinol, paracetamol, and bisphenol A.

Zhang et al..$^{[138]}$ also described the preparation of multilayer films for the modification of a GCE. They used 2,9,16,23-tetra[4-( $N$-methyl)pyridinyloxy] phthalocyaninatocobalt(II) sulfate $\left([\mathrm{TMPyPcCo}]^{4+}\right)$ as the positively charged component and acid-treated multi- 
Hybrid Materials Based on Carbon Nanotubes and Polyaromatic Molecules

Table 5. Examples of CNT/MPc hybrids used for the modification of electrodes of electrochemical sensors.

\begin{tabular}{|c|c|c|c|c|c|}
\hline CNT/MPc & Method of hybrid preparation & $\begin{array}{l}\text { Electrode and manner } \\
\text { of its modification }\end{array}$ & Analyte & $\begin{array}{c}\mathrm{LOD} \\
\mu \mathrm{M}\end{array}$ & Ref. \\
\hline $\mathrm{MWCNT/CoPc}$ & $\begin{array}{l}\text { Mixture with high purity mineral } \\
\text { oil }\end{array}$ & $\begin{array}{l}\text { GCE, adsorption } \\
\text { Immobilization of tyrosinase }\end{array}$ & $\begin{array}{l}\text { Catechol } \\
(+) \text {-Catechin }\end{array}$ & $\begin{array}{l}1.66 \\
6.32\end{array}$ & {$[133]$} \\
\hline MWCNT-COOH/CoPc & Non-covalent functionalization & $\begin{array}{l}\text { GCE modified with gold } \\
\text { nanoparticles }\end{array}$ & Acetaminophen & 0.135 & {$[134]$} \\
\hline MWCNT/CoPc & Mixing dispersions in DMF & AuNPTs/GCE, drop and dry & Diethylstilbestrol & 0.199 & [43] \\
\hline MWCNT/CoPc & - & $\begin{array}{l}\text { Pyrolytic Graphite Electrode, } \\
\text { drop and dry }\end{array}$ & $\begin{array}{l}\text { Pyridoxine } \\
\text { (vitamin B6) }\end{array}$ & 0.50 & {$[119]$} \\
\hline $\mathrm{MWCNT} / \mathrm{CoPc}$ & Mixing in a mortar with paraffin & $\begin{array}{l}\text { Solid paraffin/MWCNT/CoPc } \\
\text { composite rod electrode }\end{array}$ & Epinephrine & 0.0156 & [94] \\
\hline MWCNT/MnPc & Mixing dispersions in DMF & GCE, drop and dry & $\begin{array}{cc}\text { Catechol } & 0 \\
\text { Hydroquinone }\end{array}$ & 0.0960 .048 & {$[124]$} \\
\hline Carboxylated MWCNT/PdPc & $\begin{array}{l}\text { Mixing CNT dispersion and PdPc } \\
\text { solution in } \mathrm{H}_{2} \mathrm{SO}_{4}\end{array}$ & $\begin{array}{l}\text { Casting of CNT/Pd in Nafion } \\
\text { solution }\end{array}$ & Rutin & 0.075 & {$[48]$} \\
\hline $\mathrm{MWCNT} / \mathrm{FePc}$ & $\begin{array}{l}\text { Mixing MWCNT with FePc (1\%) } \\
\text { in paraffin oil }\end{array}$ & $\begin{array}{l}\text { Preparation of solid paraffin/ } \\
\text { MWCNT/FePc composite rod } \\
\text { electrode }\end{array}$ & Dopamine & 0.205 & {$[123]$} \\
\hline $\mathrm{MWCNT} / \mathrm{CoPc}$ & $\begin{array}{l}\text { In situ tetramerization } \\
\text { of dicyanobenzene on MWCNT } \\
\text { surface }\end{array}$ & GCE, drop and dry & Ascorbic acid & 1.0 & {$[126]$} \\
\hline $\mathrm{MWCNT} \mathrm{NH}_{2} / \mathrm{CuPc}\left(\mathrm{SO}_{3} \mathrm{H}\right)_{4}$ & $\begin{array}{l}\text { Mixing CNT dispersion } \\
\text { and phthalocyanine solution } \\
\text { in water }\end{array}$ & GCE, drop and dry & $\begin{array}{l}\text { Dopamine } \\
\text { in the presence } \\
\text { of ascorbic acid } \\
\text { and uric acid }\end{array}$ & $1-1000$ & {$[127]$} \\
\hline 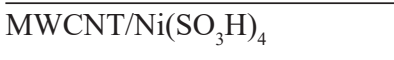 & Non-covalent functionalization & GCE, drop and dry & Dopamine & $1 \mathrm{nM}$ & {$\left[{ }^{[42]}\right.$} \\
\hline $\mathrm{MWCNT} / \mathrm{Fe}\left(\mathrm{SO}_{3} \mathrm{H}\right)_{4}$ & Non-covalent functionalization & GCE, drop and dry & Hydrazine & 0.0076 & {$[128]$} \\
\hline $\mathrm{MWCNT} / \mathrm{Co}\left(\mathrm{SO}_{3} \mathrm{H}\right)_{4}$ & Non-covalent functionalization & GCE, drop and dry & Glucose & 0.14 & [129] \\
\hline $\begin{array}{l}\text { SWCNT/nickel(II) tetra- } \\
\text { aminophthalocyaninate }\end{array}$ & Covalent functionalization & GCE, immerse and dry & 2-Mercaptoethanol & 0.15 & {$[41]$} \\
\hline $\begin{array}{l}\text { SWCNT with phenyl-amine } \\
\text { groups } / \mathrm{CoPc}(\mathrm{COCl})_{4}\end{array}$ & Covalent functionalization & GCE, immerse and dry & Diuron & 0.18 & {$[135]$} \\
\hline $\begin{array}{l}\text { SWCNT with ethylene amine } \\
\text { groups } / \mathrm{CoPc}(\mathrm{COCl})_{4}\end{array}$ & Covalent functionalization & GCE, immerse and dry & Amitrole & 0.1 & {$\left[{ }^{[69]}\right.$} \\
\hline $\begin{array}{l}\text { SWCNT with } \\
\mathrm{CONHCH}_{2} \mathrm{CH}_{2} \mathrm{NH}_{2} \text {-groups/ } \\
\mathrm{Co}(\mathrm{II}) \mathrm{Pc}\left(\mathrm{SO}_{2} \mathrm{Cl}\right)_{4}\end{array}$ & Covalent functionalization & $\begin{array}{l}\text { Screen printed carbon } \\
\text { electrode }\end{array}$ & Thiocholine & 38 & {$[136]$} \\
\hline $\begin{array}{l}\text { MWCNT/Co(II) } \\
\text { tetraaminophenoxy- } \\
\text { phthalocyaninate }\end{array}$ & $\begin{array}{l}\text { CoPc solution was dropped onto } \\
\text { GCE/MWCNT }\end{array}$ & GCE, drop and dry & $\begin{array}{l}\text { Hydrogen } \\
\text { peroxide }\end{array}$ & 0.161 & {$[130]$} \\
\hline $\begin{array}{l}\text { MWCNT-COOH/(E)-3- } \\
(2,9,16,23 \text {-tetrakis-(4-oxy-3- } \\
\text { methoxyphenyl)acrylic acid) } \\
\text { phthalocyaninatocopper(II) }\end{array}$ & $\begin{array}{l}\text { Non-covalent functionalization } \\
\text { PGE/MWCNT was immersed } \\
\text { into } \mathrm{CuPc} \text { methanol solution }\end{array}$ & $\begin{array}{l}\text { Pencil graphite electrode, } \\
\text { drop and dry }\end{array}$ & Bisphenol A & 0.0189 & {$[131]$} \\
\hline $\begin{array}{l}\text { MWCNT-COOH/tetrakis } \\
\text { (3-trifluoromethylphenoxy) } \\
\text { phthalocyaninatocobalt(II) }\end{array}$ & Non-covalent functionalization & $\begin{array}{l}\text { Pencil graphite electrode, } \\
\text { drop and dry }\end{array}$ & Nitrite & 0.062 & {$[132]$} \\
\hline $\begin{array}{l}\text { MWCNT-COOH/ } \\
\text { [tmaePcCo]I }{ }_{4} \text { (Figure 23) }\end{array}$ & $\begin{array}{l}\text { Layer by layer }(\mathrm{LbL}) \text { electrostatic } \\
\text { assembly method }\end{array}$ & GCE, LbL assembly & 4-Nitrophenol & 0.2 & {$[137]$} \\
\hline $\begin{array}{l}\text { MWCNT-COOH/ } \\
{[2,9,16,23 \text {-tetra[4-(N- }} \\
\text { methyl)pyridinyloxy] } \\
\text { phthalocyaninatocobalt(II) }\end{array}$ & Layer by layer (LbL) deposition & GCE, LbL assembly & $\begin{array}{l}\text { Nitrite, hydrogen } \\
\text { peroxide }\end{array}$ & 2.6 & {$[138]$} \\
\hline $\begin{array}{l}\text { MWCNT/Zinc(II) } \\
\text { 2(3),9(10),16(17),23(24)-tetra } \\
\text { (2-methyl-1H-imidazol-1-yl) } \\
\text { phthalocyaninate(2-)-N29, } \\
\text { N30, N31, N32 }\end{array}$ & $\begin{array}{l}\text { Immobilization } \\
\text { of ZnPc on MWCNT surface } \\
\text { in the conducting polymeric } \\
\text { matrix }\end{array}$ & $\begin{array}{l}\text { Spectroscopic grade graphite } \\
\text { rods, co-immobilization } \\
\text { of } \mathrm{GO}_{\mathrm{x}} \text { and } \mathrm{ZnPc}\end{array}$ & Glucose & 18 & [139] \\
\hline
\end{tabular}




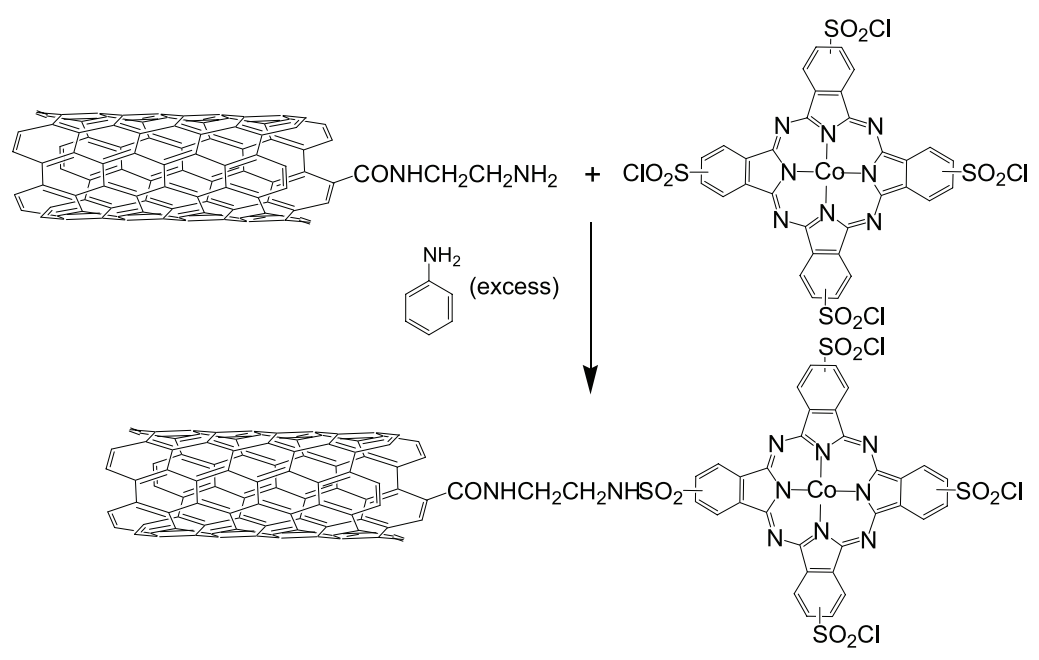

Figure 22. Scheme of the modification of SWCNTs with cobalt phthalocyanine tetrasulfonyl chloride. ${ }^{[140]}$

walled carbon nanotubes (aCNTs) as the negatively charged component for their deposition. It was shown that such electrode demonstrated excellent electrochemical sensitivity to $\mathrm{NO}^{2-}$ and $\mathrm{H}_{2} \mathrm{O}_{2}$ with the linear ranges of $5 \mu \mathrm{M}-30 \mathrm{mM}$ and $10 \mu \mathrm{M}-9 \mathrm{mM}$, respectively.

In addition to layer by layer (LbL) electrostatic assembly, deposition of Langmuir-Blodgett (LB) films of mixtures of a phthalocyanine and carbon nanotubes has been also proved to be a very useful method for the preparation of active layers of electrochemical sensors. Apetrei et $a l .{ }^{[140]}$ prepared mixed $\mathrm{LuPc}_{2} / \mathrm{CNT} \mathrm{LB}$ films. For this purpose, they dissolved $\mathrm{LuPc}_{2}$ in chloroform and CNT in ethanol. The mixtures $\mathrm{LuPc}_{2} / \mathrm{CNT}$ were first mixed together to form a monolayer at the air-water interface. The solutions containing $\mathrm{LuPc}_{2} / \mathrm{CNT}$ were spread onto ultrapure water, kept at $20{ }^{\circ} \mathrm{C}$ and after complete evaporation of the solvent the floating molecules were compressed at a speed of $10 \mathrm{~mm} \cdot \mathrm{min}^{-1}$ by two mobile barriers to obtain a $\pi$-A isotherm. The prepared $\mathrm{LuPc}_{2} / \mathrm{CNT}$ films were found to be promising for the detection of vanillic acid, pyrogallol, ascorbic acid, and catechin, due to the electrocatalytic effect induced by the electrode material, which was responsible for reducing the oxidation potential of these antioxidants.

Baba et al. ${ }^{[141]}$ also prepared nanostructured CNT/ $\mathrm{CuPc}$ hybrid multilayers using layer-by-layer self-assembly approach. SWCNTs were modified with a water-soluble cationic alcian blue pyridine derivative and anionic copper phthalocyanine-3,4',4",4'"-tetrasulfonic acid tetrasodium salt, which were then utilized for electrostatic layer-by-layer multilayer fabrication (Figure 24). It was shown by cyclic voltammetry that electroactivity of such hybrid system was enhanced due to incorporation of SWCNTs.

\section{Hybrid Materials Based on Carbon Nanotubes and Other Polyaromatic Molecules for Modification of Electrodes of Electrochemical Sensors}

Apart from phthalocyanines other aromatic molecules are widely used for the preparation of hybrid materials which are applicable for the modification of electrodes, among them derivatives of pyrene, ${ }^{[142,143]}$ anthracene, ${ }^{[143,144]}$

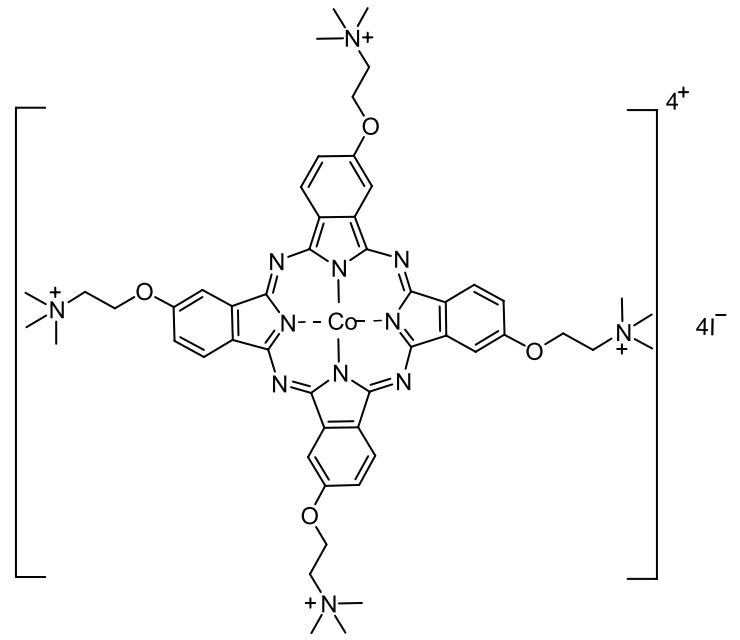

Figure 23. Cationic cobalt(II) tetra- $\beta-(N, N, N$ -

trimethylaminoethoxy)phthalocyanine $\left([\mathrm{tmaePcCo}]^{4+} \mathrm{I}_{4}^{-}\right) \cdot{ }^{[137]}$

BODIPY, ${ }^{[145]}$ coumarin,,${ }^{[75]}$ subphthalocyanine, ${ }^{[146]}$ and some others. These polyaromatic molecules are mainly utilized for the noncovalent functionalization of carbon nanotubes via $\pi-\pi$ interaction. Many examples of hybrid materials obtained by non-covalent functionalization for their application in electrochemical biosensing were described in the review of Zhou and co-authors. ${ }^{[9]}$ In this chapter, we give only a few examples of biosensors based on such hybrid materials obtained over the past decade to demonstrate the variety of the chemistry of polyaromatic molecules used to modify carbon nanomaterials.

Polyaromatic molecules can either have electrocatalytic properties themselves or be used to improve the immobilization of redox enzymes. For example, Ji et al. ${ }^{[147]}$ modified a GCE with the hybrid material obtained by non-covalent functionalization of semiconducting SWCNTs with 1-docosyloxylmethylpyrene. It was shown that the electrocatalytic activity of semiconducting SWCNTs was significantly improved after their functionalization. The prepared electrode was successfully utilized for simultaneous determina- 

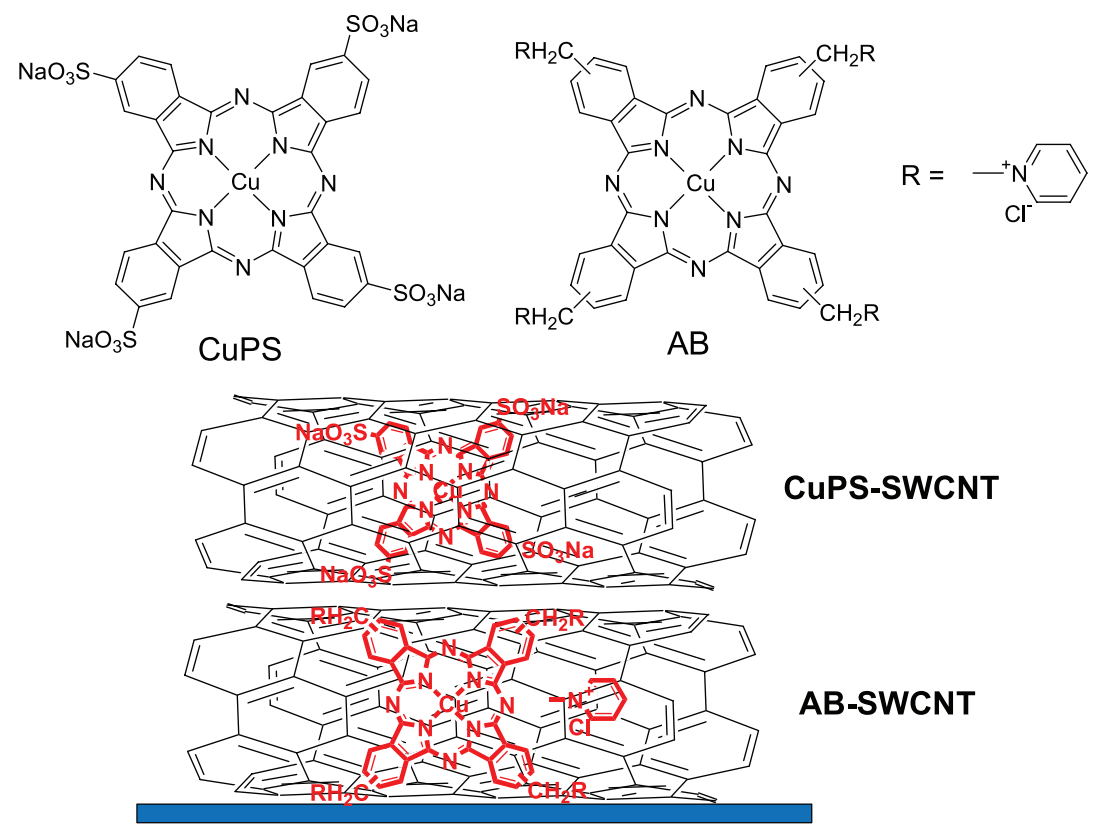

Figure 24. Schematic drawing of the fabrication of nanostructured alcian blue, pyridine variant (AB)-SWCNT/phthalocyanine-3,4',4", $4^{\prime \prime \prime}-$ tetrasulfonic acid tetrasodium salt CuPS-SWCNT LbL films. Redrawn from Ref. ${ }^{[141]}$

tion of guanine and adenine with LOD of 0.25 and $0.5 \mu \mathrm{M}$, respectively. Reuillard with co-authors ${ }^{[142]}$ used pyrene monomers bearing a boronic acid function (Figure 25A) for noncovalent functionalization of multiwalled carbon nanotubes in order to wire horseradish peroxidase (HRP) via the formation of covalent boronic ester bond with the glycosylated enzyme (Figure 25B). Then glucose oxidase $\left(\mathrm{GO}_{\mathrm{x}}\right)$ was immobilized, and the prepared bi-enzymatic system exhibited efficient bioelectrocatalytic oxygen reduction under physiological conditions.

Other pyrene derivatives, viz. 1-(2-anthraquinonylaminomethyl)pyrene, 1-[bis(2-anthraquinonyl)aminomethyl] pyrene, ${ }^{[148]}$ 1-pyrenemethyl anthracene-2-carboxylate and 1-pyrenyl anthracene-2-carboxylamide ${ }^{[143]}$ were applied for the immobilization and orientation of laccase on the surface of the MWCNT-based hybrid. This approach led to high-performance biocathodes for oxygen reduction with the maximal current density of about $1 \mathrm{~mA} \cdot \mathrm{cm}^{-2}$.
Song et al. ${ }^{[149]}$ synthesized an anthracene-tetrathiafulvalene derivative (Figure 26a) and immobilized it on single-wall carbon nanotubes through noncovalent sidewall functionalization. It was determined by differential pulse voltammetry that these hybrids interacted readily with DNA, which led to a noticeable decrease in the peak current, as well as to a positive shift of its peak potential. Thus, they may be promising materials for biomolecular recognition.

Quinone derivatives are known to show electrocatalytic ability for the reduction of $\mathrm{O}_{2}$ to $\mathrm{H}_{2} \mathrm{O}_{2}$ with an over potential much lower than that of the plain glassy carbon electrodes. Modification of MWCNTs with amino groups followed by linking with anthraquinone-2-carboxylic acid (Figure 26b) via carbodimide coupling was carried out by Tiwari et al. ${ }^{[144]}$ Glassy carbon electrode covered with this hybrid exhibited an irreversible and good electrocatalytic activity for the reduction of oxygen.
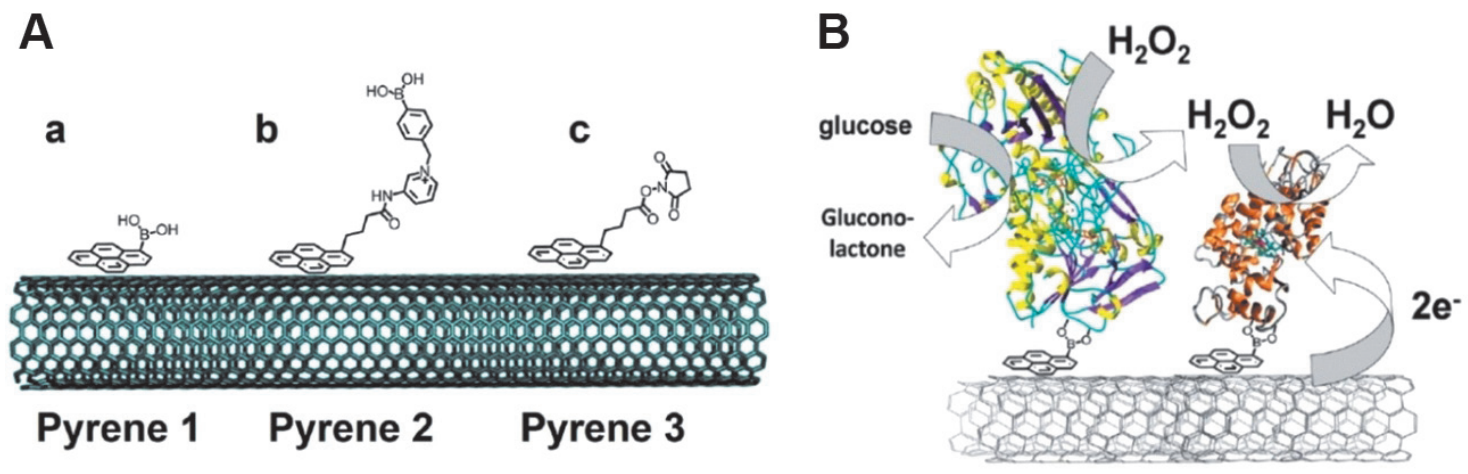

Figure 25. A: Schematic representation of MWCNTs functionalized with pyrene derivatives; B: Schematic representation of the functionalization of MWCNT electrodes with $\mathrm{GO}_{x}$ and $\mathrm{HRP}$ for the reduction of $\mathrm{O}_{2}$ into $\mathrm{H}_{2} \mathrm{O}$. Reproduced from Ref. ${ }^{[142]}$ with kind permission of Royal Society of Chemistry. 
Carbon nanotubes can also be modified with naphthalene derivatives. For example, CNTs noncovalently modified with naphthalen-1-ylmethylphosphonic acid (Figure 26c) formed fine dispersions in water and exhibited good biocompatibility for immobilization of myoglobin proteins. [150] GCEs modified using this hybrid exhibited excellent bioelectrocatalytic activity towards $\mathrm{H}_{2} \mathrm{O}_{2}$ reduction.

Mao et al. ${ }^{[151]}$ obtained a hybrid by functionalization of MWCNTs with 1,10-phenanthroline-5,6-dione (Figure 26d), which was a good electron mediator in the process of NADH oxidation. An amperometric sensor based on a GCE modified with the obtained hybrid demonstrated high sensitivity $\left(8.77 \mu \mathrm{Am}^{\cdot} \mathrm{M}^{-1}\right)$ of the detection of NADH under the potential of $0.0 \mathrm{~V}$ with minimal interference. The hybrid was also employed as a bioplatform, in which alcohol dehydrogenase was immobilized for the fabrication of ethanol biosensors. The resulting bioplatform demonstrated a LOD of ethanol of $0.30 \mathrm{mM}$.

Apart from organic aromatic molecules, there are several examples of CNT-based hybrid materials with metal complexes with aromatic ligands in the literature, e.g. $\left[\mathrm{Mn}\left(\mathrm{CH}_{3} \mathrm{COO}\right)\left(\mathrm{CH}_{3} \mathrm{OH}\right)_{2}(\right.$ pyterpy $\left.)\right] \mathrm{ClO}_{4}$, (pyterpy = 4'-(4-pyridyl)-2,2':6',2''-terpyridine $)^{[152]}$ and bis[5-((4-
${ }^{\mathrm{n}}$ decyloxyphenyl)azo $)-N$-( ${ }^{\mathrm{n}}$ ethanol)-salicylaldiminato] copper(II). ${ }^{[153]}$ The immobilization of transition metal complexes onto carbon nanotubes increased the catalytic activity of the modified surfaces. The manganese complex was shown to be a good mediator in the reaction of electrocatalytic oxidation of hydrazine and its hybrid with MWCNT was used for the determination of hydrazine with a detection limit of $0.50 \mu \mathrm{M}$. The hybrid of MWCNT with the copper(II) complex exhibited the electrocatalytic activity towards oxidation of L-cysteine.

The literature describes examples of using aromatic molecules both for covalent modification of carbon nanotubes and as linkers for creating their 3D structures. The developed surface and ability of 3D materials to incorporate electroactive molecules into the porous matrix make them very attractive for the application in electrochemical sensors. Şenocak et al. ${ }^{[146]}$ obtained a SWCNT-based hybrid by the "click" reaction between SWCNTs with azide groups and subphthalocyanine (SubPc) bearing terminal ethynyl groups (Figure 27). The SWCNT/SubPc hybrid deposited on the surface of a GCE demonstrated a good response to catechin in the concentrtation range from $0.1-1.5 \mu \mathrm{M}$ with the detection limit of $43 \mathrm{nM}$. The electrode modified

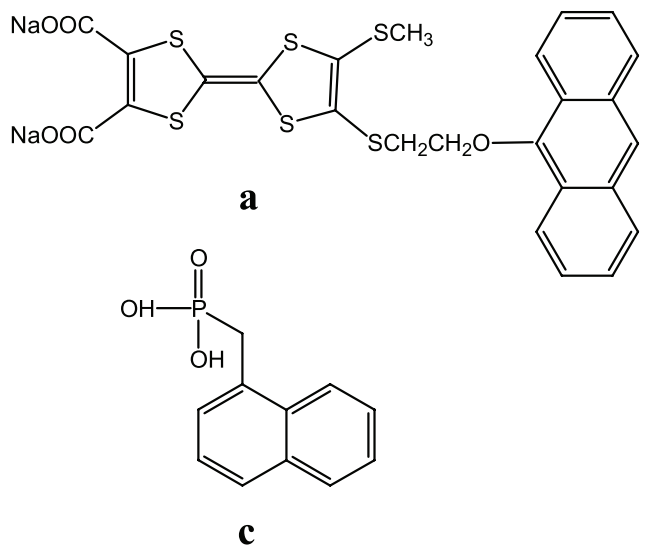<smiles>O=C1c2ccccc2C(=O)c2cc(C(O)O)ccc21</smiles><smiles>O=C1C(=O)c2cccnc2-c2ncccc21</smiles>

d

Figure 26. Examples of polyaromatic molecules used for the preparation of CNT-based hybrid materials.
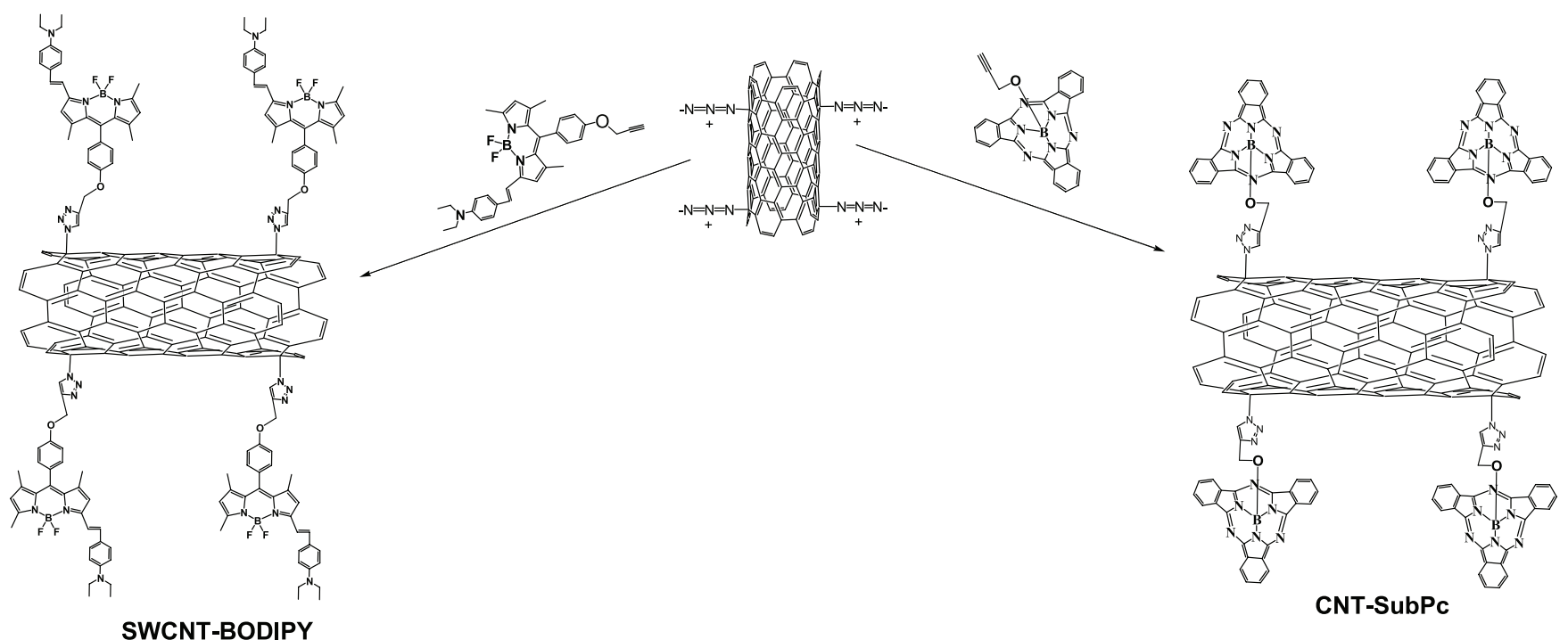

Figure 27. Scheme of the preparation of SWCNT/BODIPY and SWCNT/SubPc hybrids. ${ }^{[77]}$ 
with SWCNT/SubPc exhibited good reproducibility, stability and sensitivity to catechin in real samples of green, fruit, and black tea.

Sarığulları et al. ${ }^{[77]}$ modified SWCNTs with BODIPY derivatives containing terminal ethynyl groups (Figure 27) via the "click" reaction. The prepared hybrid was used for the detection of guanine and adenine in water solutions by the method of differential pulse voltammetry in the presence of ascorbic acid and caffeine and various ions $\left(\mathrm{Cr}^{3+}\right.$, $\mathrm{Ni}^{2+}, \mathrm{Zn}^{2+}, \mathrm{Cu}^{2+}, \mathrm{Fe}^{3+}, \mathrm{Ca}^{2+}, \mathrm{Mg}^{2+}, \mathrm{SO}_{4}^{2-}, \mathrm{NO}_{3}^{-}$and $\left.\mathrm{Cl}^{-}\right)$. The detection limits of guanine and adenine were shown to be 1.07 and $6.21 \mu \mathrm{M}$, respectively.

Authors of another work $^{[145]}$ used 4,4-difluoro-8-(4hydroxyphenyl)-2,6-diethynyl-1,3,5,7-tetramethyl-4-bora3a,4a-diaza-s-indacene having double terminal ethynyl groups as a linker for the preparation of a $3 \mathrm{D}$ hybrid
(3D SWCNT-BODIPY; Figure 28). The prepared 3D hybrid was deposited onto a glassy carbon electrode for the detection of eserine in the range of $0.25-2.25 \mu \mathrm{M}$ by the square wave voltammetry (SWV) with the detection limit of $160 \mathrm{nM}$. The hybrid material exhibited very high selectivity towards ezerine without immobilization of any enzymes due to the similarity of the reaction mechanism to that of acetylcholinesterase (AChE) enzymatic reaction. ${ }^{[154]}$

One more example of the application of 3D hybrid for modification of electrodes of electrochemical sensors was described by Şenocak et al. ${ }^{[75]}$ The authors performed a "Click" reaction to attach 7-propinyloxy-3-( $p$-propinyloxyphenyl)coumarin containing two terminal ethynyl groups to SWCNTs preliminarily modified with azide groups (Figure 29). GCEs modified with the prepared 3D

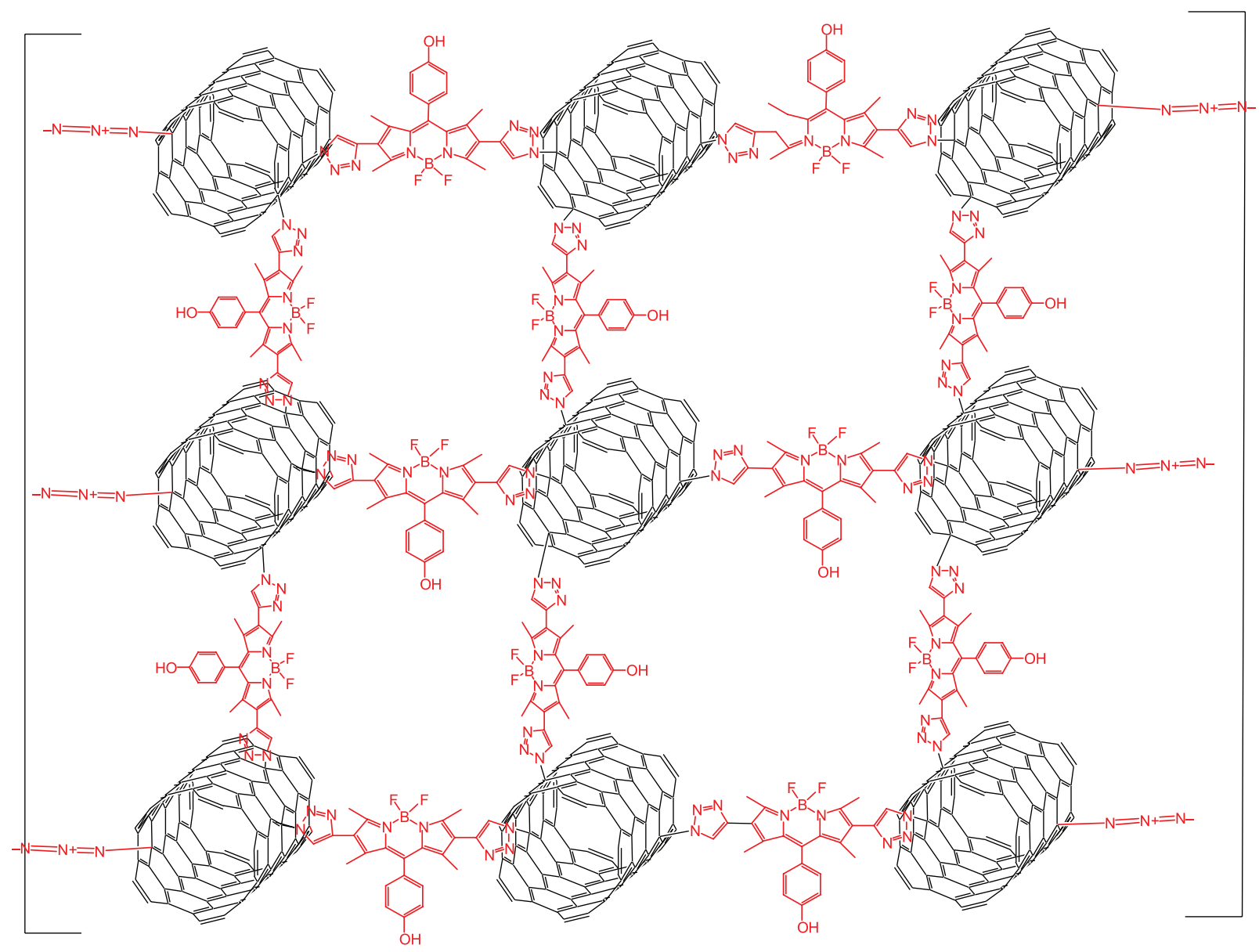

Figure 28. Scheme of the SWCNT-BODIPY 3D hybrid material. Reproduced from Ref. ${ }^{[145]}$ with kind permission of Elsevier S.A.

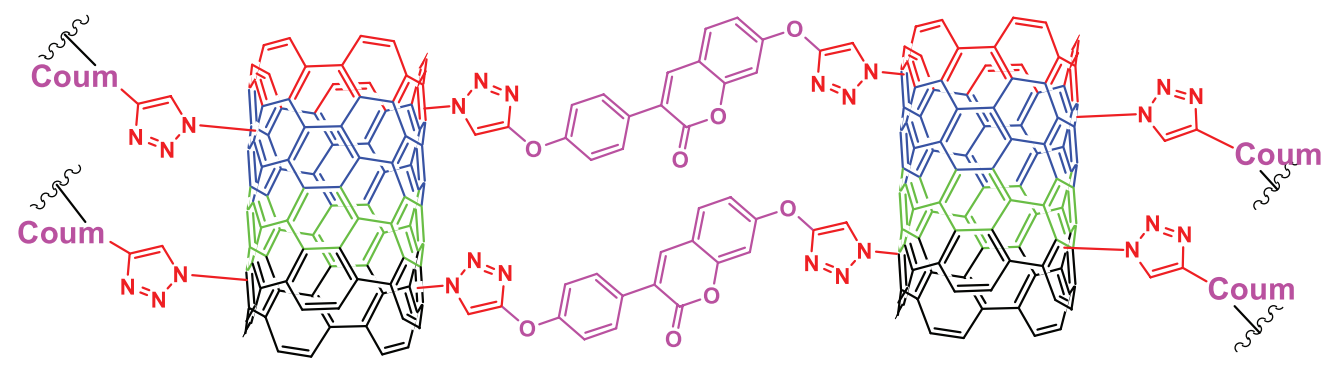

Figure 29. Scheme of the SWCNT-coumarin hybrid material. ${ }^{[75]}$ 
SWCNT-Coumarine hybrid material were used for the determination of quercetin antioxidant in water and tea; the sensor linear range was from 0.25 to $3 \mu \mathrm{M}$, while the detection and quantification limits of quercetin in water were found to be $20 \mathrm{nM}$ and $66 \mathrm{nM}$, respectively.

\section{Conclusions}

An overview of the state of research over the last ten years in the field of hybrid materials based on carbon nanotubes and various polyaromatic molecules (derivatives of phthalocyanine, porphyrin, pyrene, coumarin, BODIPY, etc.) was provided in this review. Due to the synergistic effect arising from the combination of properties of carbon nanomaterials and polyaromatic molecules the hybrid materials are widely used as active layers of chemiresistive layers and for the modification of electrodes of electrochemical sensors. For the preparation of active layers of chemiresistive gas sensors the hybrid materials are obtained by both covalent and noncovalent functionalization of carbon nanotubes with polyaromatic molecules. The functionalization degree is a very important characteristic of hybrid materials because the value of sensor response was found to be in good correlation with the degree of functionalization of SWCNTs with polyaromatic molecules. $\pi-\pi$-Interaction plays an important role in noncovalent functionalization of CNTs with aromatic molecules. It was shown that the expansion of aromatic system of molecules using for CNT functionalization led to an increase in the functionalization degree and, as a consequence, to an increase in sensitivity of the hybrid sensing layer. Covalent functionalization, and especially the creation of cross-linked 3D structures, can also enhance the degree of functionalization and sensor performance of carbon nanotubes.

The literature abounds with various examples of application of hybrid materials based on carbon nanotubes and polyaromatic molecules to modify the electrodes of electrochemical sensors. Various methods are used for the preparation of modified electrodes, among them mixing the solid components in the presence of oil or polymers in a mortar to fabricate rod electrodes, covalent or noncovalent functionalization of CNTs with the subsequent deposition of the resulted hybrid dispersion onto the electrode, layer-by-layer (LbL) electrostatic assembly and LangmuirBlodgett (LB) techniques. All these methods have their own advantages and limitations and are determined by the structure and properties of polyaromatic molecules, as well as by analytical tasks. Noncovalent functionalization of CNTs allows to preserve the original mechanical and electronic properties of CNTs and their intrinsic properties with desirable functionality, while covalent functionalization helps to prevent leaching of the electroactive component that was used to modify CNTs.

Polyaromatic molecules are widely used as linking molecules for the creation of 3D structures of cross-linked carbon nanotubes. Such 3D structures were shown to have porous structure and developed surface area, which makes them very attractive materials for the creation of both chemiresistive and electrochemical sensors with high sensitivity.
Acknowledgements. The reported study was funded by RFBR, project number 19-13-50124.

\section{References}

1. Said R.A.M., Hasan M.A., Abdelzaher A.M., Abdel-Raoof A.M.J. Electrochem. Soc. 2020, 167, 037549. doi:10.1149/19457111/ab697b.

2. Gupta V.K., Saleh T.A. Environ. Sci. Pollut. Res. 2013, 20, 2828-2843. 10.1007/s11356-013-1524-1. doi:10.1007/s11356013-1524-1.

3. Zhang T., Mubeen S., Myung N. V, Deshusses M.A. Nanotechnology 2008, 19, 332001. doi:10.1088/09574484/19/33/332001.

4. Bonegardt D., Klyamer D., Köksoy B., Durmuş M., Basova T. J. Mater. Sci. Mater. Electron. 2020, 31, 11021-11028. doi: 10.1007/s10854-020-03650-x.

5. Li J., Lu Y., Ye Q., Cinke M., Han J., Meyyappan M. Nano Lett. 2003, 3, 929-933. doi:10.1021/n1034220x.

6. Deshmukh M.A., Jeon J.-Y., Ha T.-J. Biosens. Bioelectron. 2020, 150, 111919. doi:10.1016/j.bios.2019.111919.

7. Şenocak A., Demirbaş E., Durmuş M. PhthalocyanineNanocarbon Materials and Their Composites: Preparation, Properties, and Applications. In: Nanocarbon and Its Composites (Khan A., Jawaid M., Asiri I.A., Eds.) Elsevier, 2019 pp. 677-709. doi:10.1016/B978-0-08-102509-3.00023-7.

8. Orzechowska S., Mazurek A., Świsłocka R., Lewandowski W. Materials (Basel). 2019, 13, 80. doi:10.3390/ma13010080.

9. Zhou Y., Fang Y., Ramasamy R. Sensors 2019, 19, 392. doi:10.3390/s19020392.

10. Kim, Li H. Fabrication and Applications of Carbon NanotubeBased Hybrid Nanomaterials by Means of Non-Covalently Functionalized Carbon Nanotubes. In: Carbon Nanotubes From Research to Applications (Bianco S., Ed.) InTech, 2011. doi:10.5772/18002.

11. Li H., Song S.I., Song G.Y., Kim I. J. Nanosci. Nanotechnol. 2014, 14, 1425-1440. doi:10.1166/jnn.2014.9048.

12. Liu P. Eur. Polym. J. 2005, 41, 2693-2703. doi:10.1016/j. eurpolymj.2005.05.017.

13. Woods L.M., Bădescu Ş.C., Reinecke T.L. Phys. Rev. B 2007, 75, 155415. doi:10.1103/PhysRevB.75.155415.

14. Li X., Liu Y., Fu L., Cao L., Wei D., Wang Y. Adv. Funct. Mater. 2006, 16, 2431-2437. doi:10.1002/adfm.200600339.

15. Blaudeck T., Preuß A., Scharf S., Notz S., Kossmann A., Hartmann S., Kasper L., Mendes R.G., Gemming T., Hermann S., Lang H., Schulz S.E. Phys. Stat. Sol. 2019, 216, 1900030. doi:10.1002/pssa.201900030.

16. Scherr J., Neuhaus A., Parey K., Klusch N., Murphy B.J., Zickermann V., Kühlbrandt W., Terfort A., Rhinow D. ACS Nano 2019, 13, 7185-7190. doi:10.1021/acsnano.9b02651.

17. Parra E.J., Rius F.X., Blondeau P. Analyst 2013, 138, 2698. doi:10.1039/c3an00313b.

18. Hecht D.S., Ramirez R.J.A., Briman M., Artukovic E., Chichak K.S., Stoddart J.F., Grüner G. Nano Lett. 2006, 6, 2031-2036. doi:10.1021/n1061231s.

19. Rahman G.M.A., Guldi D.M., Campidelli S., Prato M. J. Mater. Chem. 2006, 16, 62-65. doi:10.1039/b515394h.

20. Rushi A., Datta K., Ghosh P., Mulchandani A., Shirsat M. Phys. status solidi 2018, 1700956. doi:10.1002/pssa.201700956.

21. Saxena S., Saini G.S.S., Verma A.L. Bull. Mater. Sci. 2015, 38, 443-449. doi:10.1007/s12034-015-0864-5.

22. Ndiaye A., Bonnet P., Pauly A., Dubois M., Brunet J., Varenne C., Guerin K., Lauron B. J. Phys. Chem. C 2013, 117, 20217-20228. doi:10.1021/jp402787f.

23. Pauly A., Brunet J., Varenne C., Ndiaye A.L. Sensors Actuators $B$ Chem. 2019, 298, 126768. doi:10.1016/j.snb.2019.126768. 
24. Bartelmess J., Ballesteros B., de la Torre G., Kiessling D., Campidelli S., Prato M., Torres T., Guldi D.M. J. Am. Chem. Soc. 2010, 132, 16202-16211. doi:10.1021/ja107131r.

25. Chitta R., Sandanayaka A.S.D., Schumacher A.L., D'Souza L., Araki Y., Ito O., D’Souza F. J. Phys. Chem. C 2007, 111, 6947-6955. doi:10.1021/jp0704416.

26. Wang X., Liu Y., Qiu W., Zhu D. J. Mater. Chem. 2002, 12, 1636-1639. doi:10.1039/b201447e.

27. Polyakov M.S., Basova T.V. Macroheterocycles 2017, 10, 31-36. doi:10.6060/mhc161176p.

28. Polyakov M.S., Basova T.V., Göksel M., Şenocak A., Demirbaş E., Durmuş M., Kadem B., Hassan A. Synth. Met. 2017, 227 , 78-86. doi:10.1016/j.synthmet.2017.02.024.

29. Kaya E.N., Basova T., Polyakov M., Durmuş M., Kadem B., Hassan A. RSC Adv. 2015, 5, 91855-91862. doi:10.1039/c5ra18697h.

30. Guldi D.M., Rahman G.M.A., Jux N., Balbinot D., Hartnagel U., Tagmatarchis N., Prato M. J. Am. Chem. Soc. 2005, 127, 9830-9838. doi:10.1021/ja050930o.

31. Hatton R.A., Blanchard N.P., Miller A.J., Silva S.R.P. Phys. E Low-dimensional Syst. Nanostructures 2007, 37, 124-127. doi:10.1016/j.physe.2006.07.001.

32. Sun Q., Wu Z., Cao Y., Guo J., Long M., Duan H., Jia D. Sens. Actuators B Chem. 2019, 297, 126689. doi:10.1016/j. snb.2019.126689.

33. Agarwal P.B., Alam B., Sharma D.S., Sharma S., Mandal S., Agarwal A. Flex. Print. Electron. 2018, 3, 035001. doi:10.1088/2058-8585/aacc8f.

34. Das M., Ghosh S., Roy S. New J. Chem. 2018, 42, 6918-6931. doi:10.1039/C8NJ00288F.

35. Wang Y., Akhigbe J., Ding Y., Brückner C., Lei Y. Electroanalysis 2012, 24, 1348-1355. doi:10.1002/elan.201200077.

36. Chen C., Li X., Wen Y., Liu J., Li X., Zeng H., Xue Z., Zhou X., Xie X. Compos. Part A Appl. Sci. Manuf. 2019, 125, 105517. doi:10.1016/j.compositesa.2019.105517.

37. Santos D.F., Carvalho A.P.A., Soares B.G. J. Mater. Sci. 2020, 55, 2077-2089. doi:10.1007/s10853-019-04147-7.

38. Zheng J., Zong Y., Zhao G., Yu Z., Wang M., Zhu C., Li C., Liu J., Gui D. Int. J. Adhes. Adhes. 2020, 98, 102457. doi:10.1016/j. ijadhadh.2019.102457.

39. Park M., Lee H., Jang J., Park J.H., Kim C.H., Kim S.Y., Kim J. Compos. Sci. Technol. 2019, 177, 96-102. doi:10.1016/j. compscitech.2019.04.021.

40. Mugadza T., Nyokong T. Electrochim. Acta 2010, 55, 2606-2613. doi:10.1016/j.electacta.2009.12.051.

41. Mugadza T., Nyokong T. Electrochim. Acta 2010, 55, 6049-6057. doi:10.1016/j.electacta.2010.05.065.

42. Karuppiah C., Devasenathipathy R., Chen S., Arulraj D., Palanisamy S., Mani V., Vasantha V.S. Electroanalysis 2015, 27, 485-493. doi:10.1002/elan.201400551.

43. Aragão J.S., Ribeiro F.W.P., Portela R.R., Santos V.N., Sousa C.P., Becker H., Correia A.N., de Lima-Neto P. Sens. Actuators B Chem. 2017, 239, 933-942. doi:10.1016/j.snb.2016.08.097.

44. Xu Z., Li H., Sun H., Zhang Q., Li K. Chinese J. Chem. 2010, 28, 2059-2066. doi:10.1002/cjoc.201090344.

45. Li H., Xu Z., Li K., Hou X., Cao G., Zhang Q., Cao Z. J. Mater. Chem. 2011, 21, 1181-1186. doi:10.1039/C0JM02156C.

46. Wang Z., Yang X., Wei J., Xu M., Tong L., Zhao R., Liu X. J. Polym. Res. 2012, 19, 9969. doi:10.1007/s10965-012-9969-3.

47. Chen F.Y., Li K.Z., Li H.J. Adv. Mater. Res. 2013, 706-708, 15-19. doi:10.4028/www.scientific.net/AMR.706-708.15.

48. Xing R., Yang H., Li S., Yang J., Zhao X., Wang Q., Liu S., Liu X. J. Solid State Electrochem. 2017, 21, 1219-1228. doi:10.1007/s10008-016-3447-5.

49. Basiuk V.A., Flores-Sánchez L.J., Meza-Laguna V., FloresFlores J.O., Bucio-Galindo L., Puente-Lee I., Basiuk E.V. Appl. Surf. Sci. 2018, 436, 1123-1133. doi:10.1016/j. apsusc.2017.12.122.
50. Mallakpour S., Soltanian S. RSC Adv. 2016, 6, 109916-109935. doi:10.1039/C6RA24522F.

51. Ma P.-C., Siddiqui N.A., Marom G., Kim J.-K. Compos. Part A Appl. Sci. Manuf. 2010, 41, 1345-1367. doi:10.1016/j. compositesa.2010.07.003.

52. Speranza G. C - J. Carbon Res. 2019, 5, 84. doi:10.3390/ c5040084.

53. Balasubramanian K., Burghard M. Small 2005, 1, 180-192. doi:10.1002/smll.200400118.

54. Jeon I.-Y., Wook D., Ashok N., Baek J.-B. Functionalization of Carbon Nanotubes. In: Carbon Nanotubes - Polymer Nanocomposites (Yellampalli S., Ed.) InTech, 2011. doi:10.5772/18396.

55. Das R. Nanohybrid Catalyst Based on Carbon Nanotube. Cham: Springer International Publishing, 2017. 143 p. doi:10.1007/978-3-319-58151-4.

56. Hauke F., Hirsch A. Covalent Functionalization of Carbon Nanotubes. In: Carbon Nanotubes and Related Structures (Guldi D.M., Martín N., Eds.) Weinheim, Germany: Wiley-VCH Verlag GmbH \& Co. KGaA, 2010. p. 135-198. doi:10.1002/9783527629930.ch6.

57. Basha J. Applications of Functionalized Carbon-Based Nanomaterials. In: Chemical Functionalization of Carbon Nanomaterials (Thakur V.K., Thakur M.K., Eds.) Boca Raton: CRC Press, 2015. pp. 572-587. doi:10.1201/b18724-26.

58. Setaro A., Adeli M., Glaeske M., Przyrembel D., Bisswanger T., Gordeev G., Maschietto F., Faghani A., Paulus B., Weinelt M., Arenal R., Haag R., Reich S. Nat. Commun. 2017, 8, 14281. doi:10.1038/ncomms14281.

59. He N., Chen Y., Bai J., Wang J., Blau W.J., Zhu J. J. Phys. Chem. C 2009, 113, 13029-13035. doi:10.1021/jp9006813.

60. Boul P., Liu J., Mickelson E., Huffman C., Ericson L., Chiang I., Smith K., Colbert D., Hauge R., Margrave J., Smalley R. Chem. Phys. Lett. 1999, 310, 367-372. doi:10.1016/S00092614(99)00713-7.

61. Dyke C.A., Tour J.M. J. Phys. Chem. A 2004, 108, 1115111159. doi:10.1021/jp046274g.

62. Holzinger M., Abraham J., Whelan P., Graupner R., Ley L., Hennrich F., Kappes M., Hirsch A. J. Am. Chem. Soc. 2003, 125, 8566-8580. doi:10.1021/ja029931w.

63. Pastine S.J., Okawa D., Kessler B., Rolandi M., Llorente M., Zettl A., Fréchet J.M.J. J. Am. Chem. Soc. 2008, 130, 4238-4239. doi:10.1021/ja8003446.

64. Park J., Yan M. Acc. Chem. Res. 2013, 46, 181-189. doi:10.1021/ ar300172h.

65. Sonogashira K., Tohda Y., Hagihara N. Tetrahedron Lett. 1975, 16, 4467-4470. doi:10.1016/S0040-4039(00)91094-3.

66. Kumar R., Rao C.N.R. J. Mater. Chem. A 2015, 3, 6747-6750. doi:10.1039/c5ta00163c

67. Leonard A.D., Hudson J.L., Fan H., Booker R., Simpson L.J., O’Neill K.J., Parilla P.A., Heben M.J., Pasquali M., Kittrell C., Tour J.M. J. Am. Chem. Soc. 2009, 131, 723-728. doi:10.1021/ ja806633p.

68. Mugadza T., Nyokong T. Electrochim. Acta 2009, 54, 6347-6353. doi:10.1016/j.electacta.2009.05.074.

69. Mugadza T., Nyokong T. Synth. Met. 2010, 160, 2089-2098. doi:10.1016/j.synthmet.2010.07.036.

70. Ozden S., Narayanan T.N., Tiwary C.S., Dong P., Hart A.H.C., Vajtai R., Ajayan P.M. Small 2015, 11, 688-693. doi:10.1002/ smll.201402127.

71. Miyaura N., Suzuki A. J. Chem. Soc. Chem. Commun. 1979, 866-867. doi:10.1039/C39790000866.

72. De Marco M., Markoulidis F., Menzel R., Bawaked S.M., Mokhtar M., Al-Thabaiti S.A., Basahel S.N., Shaffer M.S.P. J. Mater. Chem. A 2016, 4, 5385-5389. doi:10.1039/c5ta10311h.

73. Schirowski M., Abellán G., Nuin E., Pampel J., Dolle C., Wedler V., Fellinger T.-P., Spiecker E., Hauke F., Hirsch A. 
J. Am. Chem. Soc. 2018, 140, 3352-3360. doi:10.1021/ jacs.7b12910.

74. Şenocak A., Göl C., Basova T. V, Demirbaş E., Durmuş M., Al-Sagur H., Kadem B., Hassan A. Sens. Actuators, B Chem. 2018, 256, 853-860. doi:10.1016/j.snb.2017.10.012.

75. Şenocak A., Köksoy B., Demirbaş E., Basova T., Durmuş M. Sens. Actuators, B Chem. 2018, 267, 165-173. doi:10.1016/j. snb.2018.04.012.

76. Polyakov M.S., Ivanova V.N., Basova T.V., Saraev A.A., Köksoy B., Şenocak A., Demirbaş E., Durmuş M. Appl. Surf. Sci. 2020, 504, 144276. doi:10.1016/j.apsusc.2019.144276.

77. Sarığulları H., Şenocak A., Basova T., Demirbaş E., Durmuş M. J. Electroanal. Chem. 2019, 840, 10-20. doi:10.1016/j. jelechem.2019.03.045.

78. Polyakov M., Ivanova V., Klyamer D., Köksoy B., Şenocak A., Demirbaş E., Durmuş M., Basova T. Molecules 2020, 25, 2073. doi:10.3390/molecules25092073.

79. Jombert A.S., Bayazit M.K., Coleman K.S., Zeze D.A. ChemNanoMat 2015, 1, 353-358. doi:10.1002/cnma.201500035.

80. Treacy M.M.J., Ebbesen T.W., Gibson J.M. Nature 1996, 381, 678-680. doi:10.1038/381678a0.

81. Zhang W., Zhu Z., Wang F., Wang T., Sun L., Wang Z. Nanotechnology 2004, 15, 936-939. doi:10.1088/09574484/15/8/010.

82. Travlou N.A., Bandosz T.J. Carbon N. Y. 2017, 121, 114-126. doi:10.1016/j.carbon.2017.05.081.

83. Kong J., Franklin N.R., Zhou C., Chapline M.G., Peng S., Cho K., Dai H. Science 2000, 287, 622-625. doi:10.1126/science.287.5453.622.

84. Valli L. Adv. Colloid Interface Sci. 2005, 116, 13-44. doi:10.1016/j.cis.2005.04.008.

85. Gülmez A.D., Polyakov M.S., Volchek V.V., Kostakoğlu S.T., Esenpinar A.A., Basova T.V., Durmuş M., Gürek A.G., Ahsen V., Banimuslem H.A., Hassan A.K. Sens. Actuators, B Chem. 2017, 241, 364-375. doi:10.1016/j.snb.2016.10.073

86. Singh A., Samanta S., Kumar A., Debnath A.K., Prasad R., Veerender P., Balouria V., Aswal D.K., Gupta S.K. Org. Electron. 2012, 13, 2600-2604. doi:10.1016/j.orgel.2012.07.022.

87. Parra V., Rei Vilar M., Battaglini N., Ferraria A.M., Botelho do Rego A.M., Boufi S., Rodríguez-Méndez M.L., Fonavs E., Muzikante I., Bouvet M. Langmuir 2007, 23, 3712-3722. doi:10.1021/la063114i.

88. Kumar A., Brunet J., Varenne C., Ndiaye A., Pauly A. Procedia Eng. 2015, 120, 594-597. doi:10.1016/j.proeng.2015.08.735.

89. Verma A.L., Saxena S., Saini G.S.S., Gaur V., Jain V.K. Thin Solid Films 2011, 519, 8144-8148. doi:10.1016/j. tsf.2011.06.034.

90. Jha P., Sharma M., Chouksey A., Chaturvedi P., Kumar D., Upadhyaya G., Rawat J.S.B., Chaudhury P. Synth. React. Inorganic, Met. Nano-Metal Chem. 2014, 44, 1551-1557. doi: 10.1080/15533174.2013.818021.

91. Wang B., Zhou X., Wu Y., Chen Z., He C. Sens. Actuators B Chem. 2012, 171-172, 398-404. doi:10.1016/j. snb.2012.04.084.

92. Wang Y., Hu N., Zhou Z., Xu D., Wang Z., Yang Z., Wei H., Kong E.S.-W., Zhang Y. J. Mater. Chem. 2011, 21, 3779-3787. doi:10.1039/c0jm03567j.

93. Pillay J., Ozoemena K.I. Electrochim. Acta 2009, 54, 5053-5059. doi:10.1016/j.electacta.2008.12.056.

94. Moraes F.C., Golinelli D.L.C., Mascaro L.H., Machado S.A.S. Sens. Actuators B Chem. 2010, 148, 492-497. doi:10.1016/j. snb.2010.05.005.

95. Liang X., Chen Z., Wu H., Guo L., He C., Wang B., Wu Y. Carbon N. Y. 2014, 80, 268-278. doi:10.1016/j. carbon.2014.08.065.

96. Chidawanyika W., Nyokong T. Carbon N. Y. 2010, 48, 2831-2838. doi:10.1016/j.carbon.2010.04.015.
97. Wang B., Wu Y., Wang X., Chen Z., He C. Sens. Actuators B Chem. 2014, 190, 157-164. doi:10.1016/j.snb.2013.08.066.

98. Kang D., Wang B., Wang X., Li Y., Chen Z., He C., Wu Y. Sens. Actuators B Chem. 2017, 246, 262-270. doi:10.1016/j. snb.2017.02.083.

99. Wu H., Chen Z., Zhang J., Wu F., He C., Wu Y., Ren Z. J. Mater. Chem. A 2017, 5, 24493-24501. doi:10.1039/C7TA07443C.

100. Banimuslem H., Hassan A., Basova T., Gülmez A.D., Tuncel S., Durmuş M., Gürek A.G., Ahsen V. Sens. Actuators, B Chem. 2014, 190, 990-998. doi:10.1016/j.snb.2013.09.059.

101. Kaya E.N., Tuncel S., Basova T.V., Banimuslem H., Hassan A., Gürek A.G., Ahsen V., Durmuş M. Sens. Actuators, B Chem. 2014, 199, 277-283. doi:10.1016/j.snb.2014.03.101.

102. Tuncel S., Kaya E.N., Durmuş M., Basova T., Gürek A.G., Ahsen V., Banimuslem H., Hassan A. Dalt. Trans. 2014, 43, 4689-4699. doi:10.1039/c3dt52736k.

103. Banimuslem H., Hassan A., Basova T., Esenpinar A.A., Tuncel S., Durmuş M., Gürek A.G., Ahsen V. Sens. Actuators, B Chem. 2015, 207, 224-234. doi:10.1016/j.snb.2014.10.046.

104. Kadem B., Göksel M., Şenocak A., Demirbaş E., Atilla D., Durmuş M., Basova T., Shanmugasundaram K., Hassan A. Polyhedron 2016, 110, 37-45. doi:10.1016/j.poly.2016.01.053.

105. Wu H., Chen Z., Zhang J., Wu F., He C., Wang B., Wu Y., Ren Z. J. Mater. Chem. A 2016, 4, 1096-1104. doi:10.1039/ C5TA09213B

106. Sharma A.K., Saini R., Singh R., Mahajan A., Bedi R.K., Aswal D.K. AIP Conf. Proc. 2014, 1591, 671-673. doi:10.1063/1.4872714.

107. Sharma A.K., Kumar P., Saini R., Bedi R.K., Mahajan A. AIP Conf. Proc. 2016, 1728, 020493. doi:10.1063/1.4946544.

108. Sharma A.K., Mahajan A., Bedi R.K., Kumar S., Debnath A.K., Aswal D.K. Appl. Surf. Sci. 2018, 427, 202-209. doi:10.1016/j.apsusc.2017.08.040.

109. Sharma A.K., Mahajan A., Kumar S., Debnath A.K., Aswal D.K. RSC Adv. 2018, 8, 32719-32730. doi:10.1039/ C8RA05529G.

110. Sharma A.K., Mahajan A., Saini R., Bedi R.K., Kumar S., Debnath A.K., Aswal D.K. Sensors Actuators B Chem. 2018, 255, 87-99. doi:10.1016/j.snb.2017.08.013.

111. Kumar S., Chawla S., Zou M.C. J. Incl. Phenom. Macrocycl. Chem. 2017, 88, 129-158. doi:10.1007/s10847-017-0728-2.

112. Sarkar T., Ashraf P.M., Srinives S., Mulchandani A. Sens. Actuators B Chem. 2018, 268, 115-122. doi:10.1016/j. snb.2018.04.078.

113. Sarkar T., Srinives S. Microelectron. Eng. 2018, 197, $28-32$. doi:10.1016/j.mee.2018.05.004.

114. Wei L., Lu D., Wang J., Wei H., Zhao J., Geng H., Zhang Y. Sens. Actuators B Chem. 2014, 190, 529-534. doi:10.1016/j. snb.2013.09.017.

115. Bensghaïer A., Kaur N., Fourati N., Zerrouki C., Lamouri A., Beji M., Mahajan A., Chehimi M.M. Vacuum 2018, 155, 656-661. doi:10.1016/j.vacuum.2018.07.004.

116. Zagal J.H., Griveau S., Silva J.F., Nyokong T., Bedioui F. Coord. Chem. Rev. 2010, 254, 2755-2791. doi:10.1016/j. ccr.2010.05.001.

117. Nyokong T., Bedioui F. J. Porphyrins Phthalocyanines 2006, 10, 1101-1115. doi:10.1142/S1088424606000454.

118. Bouvet M., Gaudillat P., Suisse J.-M. J. Porphyrins Phthalocyanines 2013, 17, 913-919. doi:10.1142/S1088424613300073.

119. Porto L.S., da Silva D.N., Silva M.C., Pereira A.C. Electroanalysis 2019, 31, 820-828. doi:10.1002/elan.201800789.

120. Nyoni S., Nyokong T. Electrochim. Acta 2014, 136, 240-249. doi:10.1016/j.electacta.2014.05.093.

121. Lin C.-Y., Balamurugan A., Lai Y.-H., Ho K.-C. Talanta 2010, 82, 1905-1911. doi:10.1016/j.talanta.2010.08.010.

122. Rebis T., Lijewski S., Nowicka J., Popenda L., Sobotta L., Jurga S., Mielcarek J., Milczarek G., Goslinski T. 
Electrochim. Acta 2015, 168, 216-224. doi:10.1016/j.electacta.2015.03.191.

123. Patrascu D., David I., David V., Mihailciuc C., Stamatin I., Ciurea J., Nagy L., Nagy G., Ciucu A.A. Sens. Actuators B Chem. 2011, 156, 731-736. doi:10.1016/j.snb.2011.02.027.

124. Silva S.M., de Oliveira F.M., Justino D.D., Kubota L.T., Tanaka A.A., Damos F.S., de Cássia Silva Luz R. Electroanalysis 2014, 26, 602-611. doi:10.1002/elan.201300576.

125. Porras-Gutiérrez A.G., Frontana-Uribe B.A., GutiérrezGranados S., Griveau S., Bedioui F. Electrochim. Acta 2013, 89, 840-847. doi:10.1016/j.electacta.2012.11.018.

126. Zuo X., Zhang H., Li N. Sensors Actuators B Chem. 2012 , 161, 1074-1079. doi:10.1016/j.snb.2011.12.013.

127. Sancy M.,Francisco Silva J.,PavezJ.,Zagal J.H.J. Chil. Chem. Soc. 2013, 58, 2117-2121. doi:10.4067/S0717-97072013000400048.

128. Devasenathipathy R., Palanisamy S., Chen S.-M., Karuppiah C., Mani V., Ramaraj S.K., Ajmal Ali M., Al-Hemaid F.M.A. Electroanalysis 2015, 27, 1403-1410. doi:10.1002/ elan.201400659.

129. Devasenathipathy R., Karuppiah C., Chen S.-M., Palanisamy S., Lou B.-S., Ali M.A., Al-Hemaid F.M.A. RSC Adv. 2015, 5, 26762-26768. doi:10.1039/C4RA17161F.

130. Shumba M., Nyokong T. Electroanalysis 2016, 28, 1478-1488. doi:10.1002/elan.201501058.

131. Koyun O., Gorduk S., Gencten M., Sahin Y. New J. Chem. 2019, 43, 85-92. doi:10.1039/C8NJ03721C.

132. Li P., Ding Y., Wang A., Zhou L., Wei S., Zhou Y., Tang Y., Chen Y., Cai C., Lu T. ACS Appl. Mater. Interfaces 2013, 5, 2255-2260. doi:10.1021/am400152k.

133. Apetrei I.M., Rodriguez-Mendez M.L., Apetrei C., de Saja J.A. Sens. Actuators B Chem. 2013, 177, 138-144. doi:10.1016/j. snb.2012.10.131.

134. de Holanda L.F., Ribeiro F.W.P., Sousa C.P., da Silva Casciano P.N., de Lima-Neto P., Correia A.N. J. Electroanal. Chem. 2016, 772, 9-16. doi:10.1016/j.jelechem.2016.04.021.

135. Mugadza T., Nyokong T. J. Colloid Interface Sci. 2011, 354, 437-447. doi:10.1016/j.jcis.2010.10.057.

136. Jubete E., Żelechowska K., Loaiza O.A., Lamas P.J., Ochoteco E., Farmer K.D., Roberts K.P., Biernat J.F. Electrochim. Acta 2011, 56, 3988-3995. doi:10.1016/j.electacta.2011.01.123.

137. Wu H., Guo L., Zhang J., Miao S., He C., Wang B., Wu Y., Chen Z. Sens. Actuators B Chem. 2016, 230, 359-366. doi:10.1016/j.snb.2016.02.088.
138. Zhang J., Chen Z., Wu H., Wu F., He C., Wang B., Wu Y., Ren Z. J. Mater. Chem. B 2016, 4, 1310-1317. doi:10.1039/ C5TB01995H

139. Buber E., Yuzer A., Soylemez S., Kesik M., Ince M., Toppare L. Int. J. Biol. Macromol. 2017, 96, 61-69. doi:10.1016/j. ijbiomac.2016.12.020.

140. Apetrei C., Nieto M., Rodríguez-Méndez M.L., de Saja J.A. J. Porphyr. Phthalocyanines 2011, 15, 908-917. doi:10.1142/ S108842461100377X.

141. Baba A., Kanetsuna Y., Sriwichai S., Ohdaira Y., Shinbo K., Kato K., Phanichphant S., Kaneko F. Thin Solid Films 2010, 518, 2200-2205. doi:10.1016/j.tsf.2009.09.052.

142. Reuillard B., Le Goff A., Holzinger M., Cosnier S. J. Mater. Chem. B 2014, 2, 2228-2232. doi:10.1039/C3TB21846E.

143. Giroud F., Minteer S.D. Electrochem. Commun. 2013, 34, 157-160. doi:10.1016/j.elecom.2013.06.006.

144. Tiwari I., Singh M., Gupta M., Aggarwal S.K.Mater. Res. Bull. 2012, 47, 1697-1703. doi:10.1016/j.materresbull.2012.03.031.

145. Şenocak A., Köksoy B., Akyüz D., Koca A., Klyamer D., Basova T., Demirbaş E., Durmuş M. Biosens. Bioelectron. 2019, 128, 144-150. doi:10.1016/j.bios.2018.12.052.

146. Şenocak A., Basova T., Demirbas E., Durmuş M. Electroanalysis 2019, 31, 1697-1707. doi:10.1002/elan.201900214.

147. Ji L., Yu S., Zhou X., Bao Y., Yang F., Kang W., Zhang X. Anal. Chim. Acta 2019, 1079, 86-93. doi:10.1016/j. aca.2019.06.027.

148. Bourourou M., Elouarzaki K., Lalaoui N., Agnès C., Le Goff A., Holzinger M., Maaref A., Cosnier S. Chem. - A Eur. J. 2013, 19, 9371-9375. doi:10.1002/chem.201301043.

149. Song M., Wang X., Liu W., Zuo J. J. Colloid Interface Sci. 2010, 343, 48-51. doi:10.1016/j.jcis.2009.10.084.

150. Li P., Liu H., Ding Y., Wang Y., Chen Y., Zhou Y., Tang Y., Wei H., Cai C., Lu T. J. Mater. Chem. 2012, 22, 15370. doi:10.1039/c2jm31350b.

151. Mao X., Wu Y., Xu L., Cao X., Cui X., Zhu L. Analyst 2011 , 136, 293-298. doi:10.1039/C0AN00402B.

152. Kamyabi M.A., Narimani O., Monfared H.H. J. Electroanal. Chem. 2010, 644, 67-73. doi:10.1016/j.jelechem.2010.03. 037.

153. Azadbakht A., Abbasi A.R. Russ. J. Electrochem. 2013, 49, 1127-1138. doi:10.1134/S1023193513120021.

154. Zhou Y., Wang S., Zhang Y. J. Phys. Chem. B 2010, 114, 8817-8825. doi:10.1021/jp104258d. 